San Jose State University

SJSU ScholarWorks

Master's Theses

Master's Theses and Graduate Research

Spring 2016

\title{
Exploring Racial Diversity in Caldecott Medal-Winning and Honor Books
}

Angela Christine Moffett

San Jose State University

Follow this and additional works at: https://scholarworks.sjsu.edu/etd_theses

\section{Recommended Citation}

Moffett, Angela Christine, "Exploring Racial Diversity in Caldecott Medal-Winning and Honor Books" (2016). Master's Theses. 4699.

DOI: https://doi.org/10.31979/etd.8khk-78uy

https://scholarworks.sjsu.edu/etd_theses/4699

This Thesis is brought to you for free and open access by the Master's Theses and Graduate Research at SJSU ScholarWorks. It has been accepted for inclusion in Master's Theses by an authorized administrator of SJSU ScholarWorks. For more information, please contact scholarworks@sjsu.edu. 


\title{
EXPLORING RACIAL DIVERSITY IN CALDECOTT MEDAL-WINNING AND HONOR BOOKS
}

A Thesis

Presented to

The Faculty of the Department of Information Science

San José State University

\author{
In Partial Fulfillment \\ of the Requirements for the Degree \\ Master of Information Science
}

by

Angela Moffett

May 2016 
C 2016

Angela Moffett

ALL RIGHTS RESERVED 
The Designated Thesis Committee Approves the Thesis Titled

EXPLORING RACIAL DIVERSITY IN

CALDECOTT MEDAL-WINNING AND HONOR BOOKS

by

Angela Moffett

APPROVED FOR THE SCHOOL OF INFORMATION

SAN JOSÉ STATE UNIVERSITY

May 2016

Dr. Joni Richards Bodart Department of Information Science

Beth Wrenn-Estes Department of Information Science

Nina Lindsay Oakland Public Library 


\section{Abstract \\ EXPLORING RACIAL DIVERSITY IN CALDECOTT MEDAL-WINNING AND HONOR BOOKS}

by

Angela Moffett

The Caldecott Medal, awarded annually by the American Library Association to the illustrator of the "most distinguished American picture book," is the oldest and most prestigious award for children's picture books in the United States. While the award winners have occasionally depicted racially diverse characters, it was not known to what extent the chosen winning titles have kept pace with changing racial demographics in the country. Diversity in children's literature, and the lack thereof, has become a critical issue for our time. The social implications of failing to provide an exemplary collection of picture books and other literature representative of all of the United States' citizens can be seen in our continuous struggle to reduce the impacts of racism. Research into how the Caldecott Medal awards have or have not kept pace with the racial composition of our country will help guide an informed discussion going forward and provide critical data to drive our conversations. 


\section{Acknowledgements}

This Master's Thesis is the result of support from many individuals. My appreciation goes to my committee: to Dr. Joni Richards Bodart for agreeing to chair this committee and for her invaluable advice, to Beth Wrenn-Estes for her encouragement and support in pursuing this topic, and to Nina Lindsay for her extensive review, difficult questions, and encouragement to always look deeper.

The support of the staff at the Arne Nixon Center, Henry Madden Library, California State University, Fresno was critical and this research could not have been completed without the assistance of Jennifer Crow, Curator and Jami Sanford, Library Assistant.

My enduring gratitude goes to many friends and to my family for their support and to Robert Dillman for giving me the space, resources, encouragement, and sometimes indignation, to pursue this research. Thanks also to Hannah Dillman and Margaret Rodriguez for their assistance and for keeping me company on the lengthy research trips. 


\section{Table of Contents}

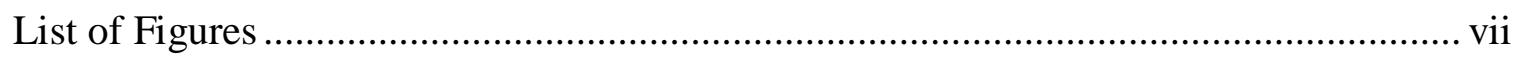

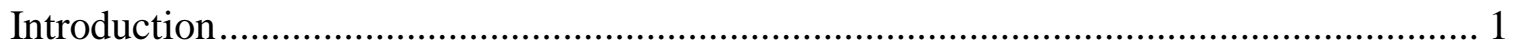

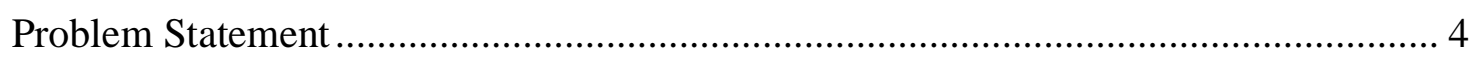

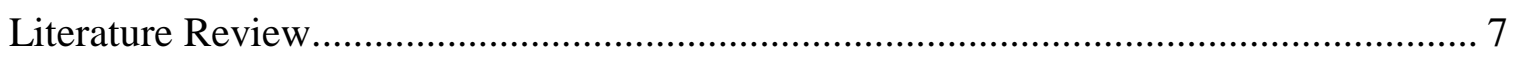

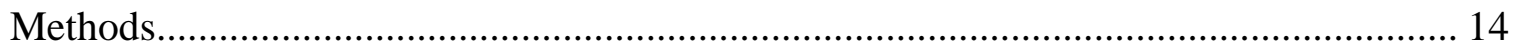

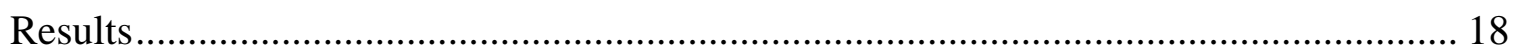

African and African American Representation......................................................... 19

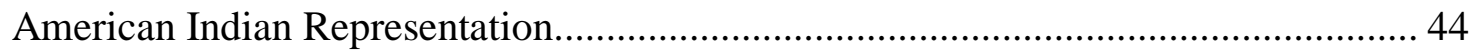

Asian and Asian American Representation ........................................................... 55

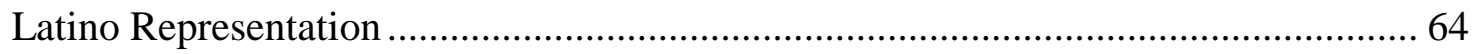

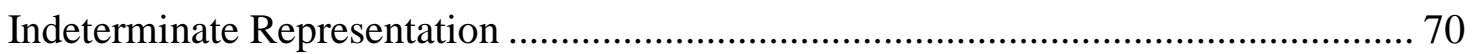

Limitations and Further Research.......................................................................... 75

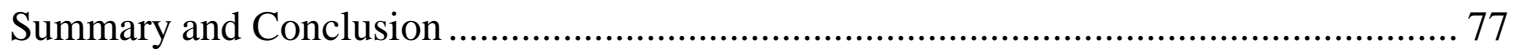

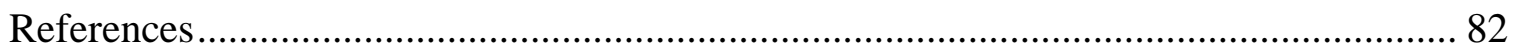

Appendix: Caldecott Award Winners ……………………..................................... 98 


\section{List of Figures}

Figure 1. Representations of African American, African, Caribbean and Jamaican people in Caldecott winning and honor books, 1939-1991

Figure 2. Representations of African American, African, Caribbean and Jamaican people in Caldecott winning and honor books, 1992-2016.

Figure 3. First images of African Americans in the 1939 biography of Abraham Lincoln. 25

Figure 4. Images from different editions of the Lincoln biography. ............................ 26

Figure 5. Caldecott titles from 1938 to 2016 including images of American Indians...... 44

Figure 6. Images of Abraham Lincoln and Chief Blackhawk from different editions of the d'Aulaires' biography of Abraham Lincoln. 46

Figure 7. Caldecott titles in which Asian and Asian American people appear, through 2016.

Figure 8. Caldecott books in which Latinos were represented, 1939-2016. 65

Figure 9. Multicultural representation vs. US population........................................ 79

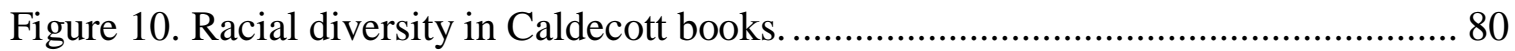




\section{Introduction}

In 1937, Frederic G. Melcher suggested establishing the Randolph Caldecott Medal, named for an influential nineteenth century illustrator, for best illustrated children's book annually (American Library Association, n.d.). He had previously launched the American Library Association's annual Newbery award for “most distinguished American children's books," and felt that an award honoring the best illustration was timely as illustrators' contributions to children's literature were just as critical as those contributions encompassed by the Newbery award. Accordingly, the Caldecott Medal was begun in 1938 and has been awarded annually since then. A winning medal (gold) is awarded each year to one illustrator and honor (silver) books are named as well, though there is no minimum or maximum number of honorees. Recipients of the prestigious award are all but guaranteed immortality in children's book publishing as they are very likely to remain in print in perpetuity (Smith, 2013).

Presently, there are 332 books — 79 medal winners and 253 honor titles-encompassing the entirety of the collection which are set forth in Appendix A.

The process of granting the award has been fine-tuned over the years to become what it is today. A revolving 15-person committee is selected annually and is composed of members of the sponsoring association (Association for Library Service to Children, a branch of the American Library Association), who work diligently throughout the year to identify the best illustrated children's books of the year. Their year-long work culminates in a days-long meeting at the American Library Association's annual midwinter meeting where they gather to hash out the details and make their final selections (Killeen, 2012). 
Selection criteria require that the work "be awarded to the artist of the most distinguished American Picture Book for Children published in the United States during the preceding year," and that the award go to the artist, who must be a U.S. resident or citizen (American Library Association, n.d.). Controversy often follows the award announcement as not everyone agrees with the year's choices for a variety of reasons. Yet even those who are not satisfied with the year's selections recognize there are strict selection guidelines in place and a professional committee overseeing the process to ensure the best outcome.

Significantly, additional awards specifically for racially diverse children's literature have been created over the years to ensure acknowledgement of exceptional work by diverse authors and illustrators. The Coretta Scott King Award for African American illustrator and author was first awarded in 1970 by the American Library Association (American Library Association, Coretta Scott King, 2016). The Pura Belpré Award for Latino/Latina writer and illustrator was first awarded in 1996 by the Association of Library Service to Children and REFORMA, the National Association to Promote Library and Information Services to Latinos and the Spanish-Speaking (American Library Association, Pura Belpré, n.d.). The Asian Pacific American Library Association and the American Indian Library Association, both affiliates of the American Library Association, issued their first awards in 2003 and 2006, respectively (Asian Pacific American Librarians Association Literature Awards, n.d.; American Indian Library Association, n.d.). These awards were most likely developed in response to lack of diversity in mainstream "white" literature. The Coretta Scott King Award in particular 
was established to "encourage and acknowledge African American authors and illustrators, in the same way the Newbery Award had been created nearly fifty years earlier, to help create a body of distinguished children's literature" (Horning, 2010, p. $13)$.

Due to the secrecy with which award committees conduct their decision-making and the fact that members pledge to never discuss their committee's process, we will never know whether the development of these diverse awards proactively enabled Caldecott committee members to maintain the status quo honoring primarily "white" literature and trust these awards to be the catchall for diverse literature. Further, due to the fact that these awards are specifically for authors and illustrators of the same racial identity about whom the literature is written, these "diversity" awards may exclude some exemplary literature about these populations, when written or illustrated by cultural outsiders. A potential obstacle for placement of these books themselves is that librarians may exclude winners in certain categories if they don't feel the population of their community would be interested in books that do not reflect their own demographics. "The implication that only blacks can write well about blacks sets up the implication that only they can read well about them, too" (Aronson, 2001, p. 273). Although librarians frequently rely on the evaluations and reviews of books from trusted sources, Aronson finds it concerning that books in some award categories may be chosen just because the librarian perceives it meets the demographic of their community rather than taking the time to become familiar with their content. He also posits that by requiring an author or illustrator to be the same race as the character about whom the book is written, these 
award committees are setting up the expectation that a good book can't be written by someone about a person of another race. Author/illustrator Virginia Hamilton and children's literature educator Rudine Sims Bishop, both African American women who took exception to Aronson's position on criteria for winning awards for diverse literature, responded to Aronson's article via letters to the editor of Horn Book Magazine. Bishop argued that with regard to the awards specifically for diverse literature, it "makes sense that those best able to illuminate those experiences would be those who have been closest to it." At the time of this discussion, only the Coretta Scott King and Pura Belpré awards had been established and she stated that both awards were "about recognizing that cultural distinctiveness and celebrating literary and artistic excellence created by people who have "talked the talk and walked the walk"” (Bishop, 2001). Hamilton likewise opined in opposition to his declarations and offered instead that there "is a difference in the way a member of Parallel Culture community writes about the community through her own experience from the way one outside of that community might write about it." Indeed, according to Hamilton, "Race and culture and social consciousness give Parallel Culture artists and writers unique insights" (Hamilton, 2001).

\section{Problem Statement}

In 2015, the Caldecott medal was awarded to Dan Santat, an Asian American author and illustrator, and three of the six honor books were by authors from underrepresented backgrounds (Barthelmess, 2015). While 2015's Caldecott winners were the most diverse yet, the announcement arrived on the heels of some insensitive and racist incidents in the children's literature community. In April 2014, as preparation for 
the inaugural BookCon was underway, Publisher's Weekly announced that "Blockbuster Reads: Meet the Kids' Authors That Dazzle" would assemble Jeff Kinney, James Patterson, Rick Riordan, and Lemony Snicket on the same stage for the first time (Kirch, 2014). At this May 31 event, the authors would discuss the inspiration behind their novels and characters, shed light on their creative processes, and offer a peek at what fans could expect next. The event was described as an "unprecedented, power-packed panel" of the "world's biggest children's authors." However, a "number of industry observers expressed their displeasure on Twitter about the lack of diversity" on this panel and, in quick response, the non-profit We Need Diverse Books was established almost overnight (“We need diverse books," n.d.).

Not long after, in November 2014, African American female Jacqueline Woodson received the National Book Award for Young People's Literature for her book Brown Girl Dreaming. The man presenting the award—white author Daniel Handler (a.k.a. Lemony Snicket and one of the members of the aforementioned BookCon panel)— announced as he presented the award to Ms. Woodson, "Jackie's allergic to watermelon. Just let that sink in your mind." The backlash was so quick and immense that Handler apologized via Twitter within 36 hours, made a $\$ 10,000$ donation to We Need Diverse Books and matched another $\$ 100,000$ in donations. Gracious in the aftermath, Woodson's response in the New York Times explained her mission "to write stories that have been historically absent in this country's body of literature, to create mirrors for the people who so rarely see themselves inside contemporary fiction, and windows for those who think we are no more than the stereotypes they're so afraid of" (Woodson, 2014). 
The Cooperative Children's Book Center of the University of WisconsinMadison's School of Education (CCBC) has provided annual statistics on the diversity of published children's books since 1994 and statistics for African American representation since 1985. Their statistics for year 2014 (the most recent year for which there are population estimates from the U.S. Census Bureau), indicate that of an estimated 5,000 children's books printed, the CCBC received 3,400 for review. Of those 3,400 reviewed, 292 (or 9\%) were written by people of color and 396 (or 12\%) were about people of color (Cooperative Children's Book Center, 2016, March 25). The U.S. Census Bureau's estimate in 2014 was that $37.9 \%$ of the United States population identified their race as something other than "non-Hispanic White" (United States Census Bureau, 2016, March 22). It is quickly apparent that even with a large margin in the statistics to account for nonfiction books about subjects other than people or fiction books whose protagonists are animals, racially diverse populations are nowhere near equally represented as characters in children's literature, let alone as authors. Further, these statistics do not account for the fact that $23.1 \%$ of the population is under 18 (United States Census Bureau, 2016), and in the case of these primary consumers of children's literature, racial diversity is greater than the national average and growing rapidly (Klein, 2015).

It is commonly held that literature shapes thought, and thought shapes society. As Quinn claims, "studies of cultural artifacts provide information about what a culture holds as valued as well as insight into how the participants of a culture make meaning" (Quinn, 2006). What do our artifacts reveal about us? With such significance, it is no 
wonder that social scientists will occasionally pursue an understanding of how children's literature is mirroring society, or how society is mirroring children's literature.

Although the dialog continues among children's literature professionals, and it is frequently acknowledged that there is a lack of adequate multicultural literature, the selections of the award committees have made no consistent progress to address it. As the literature reviewed below will demonstrate, given the unprecedented diversity of the 2015 Caldecott recipients and the momentum of the \#WeNeedDiverseBooks campaign, an examination of racial diversity as depicted in Caldecott Medal and honor books, compared to changing racial demographics in the United States, is an area overdue for scrutiny.

\section{Literature Review}

As the oldest and longest-running award for children's picture books in the United States, the Caldecott canon is frequently utilized for research examining the culture of children's picture books, including within the broader context of concurrent social issues. Detailed studies have included examinations of the depiction of fatherhood, civil rights, gender, and environmental conservation (Crisp \& Hiller, 2011; Sasser, 2014; SillsBriegel \& Camp, 2001; Williams, Podeschi, Palmer, Schwadel, \& Meyler, 2012). Still others have used the Caldecott collection as just a small piece in a much larger puzzle of examining racism in the United States (Pescosolido, Grauerholz \& Milkie, 1997; Williams, \& Deyoe, 2014). Most researchers of the topics above have indicated that they selected Caldecott books because they were a controllable, easily identified subset that were not only likely to be in print but which, due to the predictability of their continuous 
publication, would be books to which generations of children would be exposed as libraries continued to reintroduce them (Crisp \& Hiller, 2011, 198; Quinn, 2006, 74; Williams et al., 2012).

Researchers felt examination of picture books, a media with which children regularly interact, would be meaningful because of its "widespread availability in the United States, its use as an instructional tool, and its enduring 'shelf-life"' (Quinn, 2006, 74). Selection of Caldecott winners as the examined body of literature was often cited as a particularly useful choice because of the stipulation that they be illustrated by a U.S. citizen and published by an American publisher (Crisp \& Hiller, 2011; Quinn, 2006; Williams et al., 2012). Conversely, it was also acknowledged that these criteria did not necessarily hold that the books were popular with children, but in order to create a predictable subset for exploration, each reviewing team had to make a decision and choose a body of work (Quinn, 2006). Other researchers used the collection, along with yet other subsets of children's literature, to look at how the culture of children's books reflected social conflicts for African Americans in particular (Pescosolido et al., 1997).

As part of the process of reviewing how fatherhood was portrayed over the years, for instance, researchers scrutinized Caldecott winners and honorees covering the years 1938-2002. They gathered data on how both mothers and fathers were depicted for purposes of comparing the different roles and to see how the changing face of the nation was represented in picture books. Due to their selection as Caldecott titles, the books were fairly easy to access for scrutiny. Each team had to create a list of codes to note search criteria as it appeared in the pictures and/or text, requiring several reads. The 
researchers of each social issue used different controls with some having a single reviewer, others comprising the team of authors, and still others composed of larger review groups (Quinn, 2006).

As a vehicle for exploring how Civil Rights-Era African Americans felt about the representation of Blacks in picture books, M. Tyler Sasser looked at the response to the publication of Ezra Jack Keats' 1963 Caldecott-winning The Snowy Day among Black thought leaders of the time. As Keats was a white male, these leaders were divided in their response to his success. The old guard within the Civil Rights movement, including people such as Langston Hughes, Charlemae Hill Rollins, and others, were delighted to have African American children appearing in mainstream (i.e., "white") picture books. Yet the new face of the Black Power Movement, including Malcolm X and others, did not want a white man legitimizing the experience of African American youth by telling the stories that rightfully belonged to them. Significantly, this appears to be the beginning of a discussion that continues today: who is entitled to give a voice to African American or other people of color (Sasser, 2014)? At that time, "librarians, authors, illustrators and scholars of African American children's literature split ... into two camps: those who define the genre solely by authorship (i.e., only African Americans can write African American literature), and those who define the genre by the content of the book" (Sasser, 2014, 372).

In the case of the team researching depictions of fatherhood, of particular interest was "the intersection of cultural and possible symbolic phenomena with historical events and patterns" (Quinn, 2006). They were following in the footsteps of others who had 
researched the culture of fatherhood vis-à-vis comics, magazine articles, and television commercials which they felt were possible sources of role identity and would thus influence picture book illustration. Interestingly, it was believed that “the children's book field...developed alongside, if not together with, the organized Left" and "helped to make children's literature a key outlet for leftists in the mid-twentieth century" (Sasser, $2014,362)$.

The team who studied gender in Caldecott winning books (1938-2011) collected data on how gender is represented in each of the books as well as the gender of the author and illustrator. To keep their research consistent with similar researchers, they only looked at the medal winners, of which there were 74 . The research team actively negotiated their coding determinations throughout the process so the coding of gender was dynamic to the end (Crisp \& Hiller, 2011).

The researchers investigating how African Americans were portrayed in picture books during times of significant black-white societal conflict discovered that when dominant norms were being challenged, "Blacks virtually disappear from U.S. picture books." This team took on the monumental task of examining Caldecott winners, Little Golden Books, a sampling of books from the Children's Catalog, the Horn Book advertising and editorial content, and event summaries listed in the New York Times Index for the decades spanning the 1930s through the 1990s (Pescosolido et al., 1997).

The researcher examining leadership in children's literature focused on all medal winners and "selected" honorees. Because they used a specific leadership model (i.e., Kouzes and Posner), its usefulness was somewhat limited to those whose interests 
extended to their management techniques. However, it is interesting to note that their findings revealed that many leadership concepts are accessible in children's literature and could serve as models in lesson planning for children's learning environments (Boulais, 2002).

There was also much "chicken or egg" contemplation among researchers as to whether society was mirrored in picture books or if picture books set the pace for society (Quinn, 2006). However, researchers of gender depiction noticed marked spikes in female winners during the 1960s "famous for the Civil Rights and women's liberation movements" and a tapering off through the seventies, only to conclude the most recent decade with the highest male to female ratio yet and Quinn and others found that fatherhood depictions fluctuated concurrent with other media (Crisp \& Hiller, 2011; Quinn, 2006).

Also of additional concern to researchers was the role picture books might play in the nation's changing response to environmental concerns. They noted at the outset that two contributing factors might be playing a role in Americans' waning concern for the environment amidst increasing environmental problems (Williams et al., 2012). Specifically, they wanted to examine if the diminishing concern could be due to a lack of natural environments in picture books or if it could be due to increased isolation from nature as more youth live in urbanized areas and turn to electronic resources as their primary interaction. Their findings support the isolation theory (Williams et al., 2012).

In addition to the research regarding the Caldecott medal's place in our social milieu, several articles examined the winners' experiences following receipt of the 
prestigious award (Glass, 2013; Smith, 2013; Verbeten, 2013). Former Caldecott selection committee members shared some aspect of their experience, their research, or their perception of the winners' experiences post-award. All of these articles originated in Children and Libraries, the publication of the Association for Library Services to Children, the Caldecott-awarding body, in the Spring 2013 issue. There is definitely opportunity for further research in this regard as most of these are pieces celebrating the authors and much could be done to explore their writing experience.

Finally, of potential general interest with regard to the Caldecott Medal is the research surrounding the significance of the selected literature. According to Pauline Davey Zeece in And the Winner Is: Children's Literature Awards and Accolades, "There are currently over several hundred awards recognized in the field of children's literature in the United States," and they come with a myriad of different requirements (Zeece, 1999, 233-234). That a number of researchers chose to focus on Caldecott winners is no surprise given the finite nature of the Caldecott and the varying criteria for most of the other awards. As a potential research project, one could choose to examine best sellers or other award winners for greater depth, variety or focus, depending on the nature of one's research. The research of Ujiie and Krashen revealed that "very few award winners" were on the fiction bestseller list but that that did not keep librarians from stocking both the award winners and the bestsellers (Ujiie \& Krashen, 2006). However, the award winners will stay in a library's collection long after popularity of contemporary bestsellers fades. 
Interestingly, the American Library Association has added special awards for diverse audiences over the years, including the Pura Belpré Award, established in 1996, and awarded "annually to a Latino/Latina writer and illustrator whose work best portrays, affirms, and celebrates the Latino cultural experience in an outstanding work of literature for children and youth." Additionally, the Coretta Scott King Book Awards are given annually to outstanding African American authors and illustrators of books for children and young adults which demonstrate an appreciation of African American culture and universal human values (American Library Association, Welcome to the Pura Belpré, n.d.; American Library Association, About the Coretta Scott King, 2016.). While these awards do not yet have the same level of popular exposure and market impact as a Caldecott Medal, they are prestigious in their own right.

It is widely believed that a culture's values will be held in its artifacts, of which picture books are a part (Quinn, 2006) and that "picture books often play an important role in socialization" (Williams et al., 2012). In fact, a "primary means of transmitting cultural values from one generation to the next is through the telling of stories and, in the United States, this commonly comes in the form of picture books" and that children's picture books "legitimize and validate experiences, providing spaces that allow readers to locate images of themselves and the people they love" (Crisp \& Hiller, 2011, 197, 210).

Conspicuously absent from this body of literature is a focused examination of the appearance of racial diversity within the text and illustrations of the Caldecott genre as well as the diversity of authors and illustrators themselves. Closing this gap in knowledge with a close examination of racial diversity within the Caldecott collection is 
critical to more fully understanding these culturally and socially significant materials and to help guide the conversation about diverse inclusion moving forward.

Analysis of the content of diversity in children's books has been undertaken by many researchers in the past. Recently and significantly, Melanie D. Koss, an associate professor in the Department of Literacy and Elementary Education at Northern Illinois University, undertook analysis of a collection of picture books from 2012. She and her team examined a subset of 455 books published that year applying an analytical lens which examined each book's content for ethnicity, gender and disability. Author and illustrator gender and ethnicity were likewise recorded. Their study concluded that children "who interact with current picturebooks predominantly see White faces and receive the message that [therefore] according to scholars of CRT, to be White is to be better" (Koss, 2015, 37). Applying a similar lens to examination of the Caldecott collection, along with an examination of our changing racial demographics, will reveal at what pace our changing population has been paralleled in the winners of this significant award.

\section{Methods}

Objectives for this research included analysis of (a) how racial diversity has been depicted in Caldecott winning and honor books, both in the text and illustrations; (b) the racial diversity of the books' illustrators and authors themselves; and (c) comparison of both to the changing racial diversity in the United States. A preliminary review revealed that these factors have not kept pace with each other. A lack of diverse representation in picture books upholds a fear of the "other" that is perpetuated in our racist society. 
Bringing a greater focus on the disparity between publication choices and award selection will hopefully highlight the importance of continued efforts to ensure that books representative of our diversity are selected for publication and awards. Along with those efforts should come increased awareness that the books our youth need are books that honor the diversity in their lives.

The method of analysis for this study centered on a detailed quantitative review of each of the 332 winning and honor books from 1938-2016 as primary sources. The complete list of all Caldecott award winning (medal and honor) books, is available on the American Library Association's website and incorporated herein as Appendix A. Access to these books was fairly unimpeded, with the majority of the items collected in the Arne Nixon Center for the Study of Children's Literature at the Henry Madden Library, California State University, Fresno, and the remainder in public library rare book collections in the San Francisco Bay Area where the researcher lives.

As was the case with other research focusing on Caldecott books as described in the literature review essay above, an initial read of each book was necessary to establish final variables for coding. Research started with examination and recording of the following data:

- Title

- Year of award

- Gold or silver award recipient

- Genre

- If books are about inanimate, animal or human characters 
- If human characters, record appearances of people for race, gender, and role (primary, secondary, or background)

- Any languages represented other than English

- Location

- Culture depicted

- Author race and gender

- Illustrator race and gender; and

- Citation.

Roles of characters were calculated as follows:

- Primary character was specified when the images depicted are of the character the book is about or from whose voice the story is told;

- Secondary character was used when the image is a character interacting with a primary character or if the story was not about them but they were significant enough to be called out in the text;

- Background character was used when the image is of a character represented on the page not interacting with the primary character.

This data was gathered during an initial review. Some anomalies were accepted in such instances where a place (e.g., Harlem) or thing (e.g., In the Small, Small Pond) serves as the primary character.

A second, detailed review of the Caldecott books featuring people from diverse cultures examined the quality of how people were depicted. This portion was conducted either in concert with an additional person and/or with someone spot-checking accuracy 
in assessment. To settle potential interpretive conflicts, yet another researcher reviewed "indistinct" representations, such as where racial identity was designated as "Indeterminate."

Review of illustrator and author biographies of Caldecott winners and honorees helped to reveal their ethnicities. This was accomplished through internet research, publisher descriptions and, for contemporary titles, reviews of the book jacket biographies and author or publisher websites.

Readily available on the internet, United States census data served as the data with which to compare book diversity to racial demographics. Similar to the previous studies of Caldecott winners and honorees examined in the literature, the comparisons were broken down with the reporting of decennial census data (i.e., 1938-39; 1940-49; 1950-59; and so forth). Demonstrable arcs in changes in diversity are evident in visual graphics extrapolated from the comparison to the two data sets.

Collection and synthesis of the aforementioned data allows research into how our diverse and changing racial demographic have been reflected in these award-winning children's picture books. While data was collected about the role(s) played by white characters in the winning and honor Caldecott titles, they were not scrutinized further for purposes of this study inasmuch as there is no lack of white representation and the purpose of this research was to focus on representation of diverse populations.

In addition to the quantitative analysis, the researcher undertook qualitative analysis of all books which featured a person who fell into one of the predetermined categories of Africans/African-Americans, American Indians/First Nations, Asian 
Pacific/Asian Pacific Americans or Latinos. This closer examination of the quality of representation took note of how these races or cultures have been represented.

The predetermined categories are based on the categories in use by the CCBC, which receives most of the books published annually for youth in the United States for collection and examination. In 1985, the CCBC started recording which of the books they received were written and/or illustrated by or were about African Americans. Then in 1994, the CCBC also started tracking the same data with respect to Asian Pacific/Asian Pacific Americans, First Nation/American Indians and Latinos. Finally, beginning in 2002, the CCBC began sharing the data they collected each year (CCBC, 2015). Because the CCBC has been a pioneer in the collection of data regarding diversity in children's literature and because their research continues to shape much of the conversation regarding said diversity, this was the criteria and language used in this study as well.

\section{Results}

An initial review of the Caldecott canon revealed that diversity as represented in the United States' children's literature has not kept pace with the diversity of the United States' children and, in particular, the award-winning literature that is destined to stay in the hands of future generations of children. Knowing the data behind this important foundation for our youth may help demonstrate the necessity for more diversity in children's literature as the disparity in representation is revealed. It is possible that the fact that we, as a society, are not providing enough windows and mirrors to our youth is one of the reasons that racism continues to be so prevalent and why the "other" continues 
to be stigmatized in American culture. Through the medium of picture books, we have the opportunity to increase awareness of other cultures and identities and, with this awareness, acceptance and familiarity with differences. Stories of the everyday such as More More More Said the Baby and All the World depict people of multiple races interacting and living out their lives in ways likely to be familiar to most children, offering mirrors with either their own or a different colored face. These are opportunities to see what they have in common with other people. Last Stop on Market Street gives the reader an opportunity to see themselves if they live in a similar urban environment but also a chance to see through a window into another's life and how those surroundings and experiences may differ from the reader's.

Another interesting discovery among the data is that although a number of books included multiple races, there were fewer books that told a story solely about or from the perspective of one race only. It was discovered out of the 332 books, $7 \%$ featured only Africans/African Americans (22), 3\% featured only American Indians (10), 4\% featured only Asians/Asian Americans (13), 2\% included only Latinos (6), 1\% featured only indeterminate characters (4), 14\% included only inanimate or animal characters (47) and $52 \%$ included only white characters (173).

\section{African and African American Representation}

Black people have been visually represented in the winning and honor Caldecott titles a total of $19 \%$, or in 62 of the 332 books. They have been featured exclusively in these 62 books 22 times, or in $7 \%$ of the total Caldecott titles. These representations include African American, African, Caribbean and Jamaican people. As primary 
characters, they have appeared in 29, two of which were medal winners (see Figures 1 and 2). Among the Caldecott books featuring Africans or African Americans, 22 have been illustrated by African American artists and 15 have been written by African American authors. Additionally, several books have been illustrated or written by an African American that did not feature Black people. Some of those titles are included under "Indeterminate," and the others are Freight Train and Truck, both illustrated and written by Donald Crew; The Story of Jumping Mouse illustrated and written by John Steptoe; and The Ugly Duckling, Noah's Ark and The Lion \& the Mouse, all by Jerry Pinkney.

The first appearance of an African American primary character in a winning title was The Snowy Day in 1963. This was followed by The Smoky Night in 1995. The first appearance of an African American author and illustrator came the same year, in 1972, when Tom and Muriel Feelings won an honor award with Moja Means One: A Swahili Counting Book. The first African American illustrator of a medal winner was Leo Dillon in 1976 with Why Mosquitoes Buzz in People's Ears and the first African American to author a winning title was Jerry Pinkney whose The Lion and the Mouse, a wordless book, won in 2010 . 


\begin{tabular}{|c|c|c|c|c|c|c|c|c|}
\hline Title & \multirow{2}{*}{$\begin{array}{l}\text { Illustrator } \\
\text { James Daugherty }\end{array}$} & Author & Year & 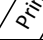 & \multirow[t]{2}{*}{10} & & \multirow{2}{*}{$\mathbf{x}$} & \\
\hline Andy and the Lion & & James Daugherty & 1939 & & & & & \\
\hline Abraham Lincoln & Ingri \& Edgar Parin d'Aulaire & Ingri \& Edgar Parin d'Aulaire & 1940 & & & & $\mathbf{x}$ & $\mathbf{x}$ \\
\hline They Were Strong and Good & Robert Lawson & Robert Lawson & 1941 & & & & $\mathbf{x}$ & $\mathbf{x}$ \\
\hline An American $\mathrm{ABC}$ & Maud \& Miska Peterham & Maud \& Miska Petersham & 1942 & & & & $\mathbf{x}$ & \\
\hline Small Rain: Verses from the Bible & Elizabeth Orton Jones & Jessie Orton Jones & 1944 & & & & $\mathbf{x}$ & \\
\hline Prayer for a Child & Elizabeth Orton Jones & Rachel Field & 1945 & & & & $\mathbf{x}$ & $\mathbf{x}$ \\
\hline The Rooster Crows & Maud Petersham & Miska Petersham & 1946 & & & & $\mathbf{x}$ & \\
\hline Sing in Praise: & Marjorie Torrey & Opal Wheeler & 1947 & & & & $\mathbf{x}$ & \\
\hline Henry Fisherman & Marcia Brown & Marcia Brown & 1950 & $\mathbf{x}$ & & & $\mathrm{x}$ & $\mathbf{x}$ \\
\hline Dick Whittington and his Cat & Marcia Brown & Marcia Brown & 1951 & & & & $\mathbf{x}$ & \\
\hline If I Ran the Zoo & Dr. Seuss & Dr. Suess & 1951 & & & & $\mathbf{x}$ & \\
\hline Fly High, Fly Low & Don Freeman & Don Freeman & 1958 & & & & & \\
\hline A Snowy Day & Ezra Jack Keats & Ezra Jack Keats & 1963 & $\mathrm{x}$ & & & $\mathrm{x}$ & \\
\hline Why the Sun and the Moon Live in the Sky & Blair Lent & Elphinstone Dayrell & 1969 & & & & $x$ & \\
\hline Goggles! & Ezra Jack Keats & Ezra Jack Keats & 1970 & $\mathbf{x}$ & & & $\mathrm{x}$ & $\mathbf{x}$ \\
\hline A Story A Story & Gail E. Haley & Gail E. Haley & 1971 & $\mathbf{x}$ & & & $\mathrm{x}$ & $\mathbf{x}$ \\
\hline Moja Means One & Tom Feelings & Muriel Feelings & 1972 & & & & & \\
\hline Jambo Means Hello & Tom Feelings & Muriel Feelings & 1975 & & & & $x$ & $\mathrm{x}$ \\
\hline Why Mosquitos Buzz in People's Ears & Leo \& Diane Dillon & Verna Aardema & 1976 & & & & & \\
\hline Ashanti to Zulu: African Traditions & Leo \& Diane Dillon & Margaret Musgrove & 1977 & & & & & \\
\hline
\end{tabular}

Figure 1. Representations of African American, African, Caribbean and Jamaican people in Caldecott winning and honor books, 1939-1991. Data compiled from author's research. 


\begin{tabular}{|c|c|c|c|c|c|c|c|c|c|}
\hline Title & Illustrator & Author & Year & & & & & & \\
\hline Tar Beach & Faith Ringgold & Faith Ringgold & 1992 & & $\mathrm{X}$ & $\mathbf{x}$ & $\mathrm{x}$ & $\mathbf{x}$ & $\mathrm{x}$ \\
\hline Working Cotton & Carole Byard & Sherley Anne Williams & 1993 & & $\mathrm{x}$ & $\mathrm{x}$ & $\mathrm{x}$ & $\mathbf{x}$ & $\mathrm{x}$ \\
\hline Grandfather's Journey & Allen Say & Allen Say & 1994 & & & $\mathbf{x}$ & & & \\
\hline Yo! Yes? & Chris Raschka & Richard Jackson (edited) & 1994 & $\mathrm{x}$ & & & & & \\
\hline Smoky Night & David Diaz & Eve Bunting & 1995 & $x$ & & & $\mathrm{x}$ & $\mathrm{x}$ & $x$ \\
\hline John Henry & Jerry Pinkney & Julius Lester & 1995 & $\mathrm{x}$ & & $\mathrm{x}$ & $\mathrm{x}$ & $\mathbf{x}$ & $\mathrm{x}$ \\
\hline Swamp Angel & Paul O. Zelinsky & Anne Issacs & 1995 & & & & & $\mathrm{x}$ & $\mathrm{x}$ \\
\hline Zin! Zin! Zin! A Violin & Majorie Priceman & Lloyd Moss & 1996 & & & & $\mathrm{x}$ & & \\
\hline The Faithful Friend & Brian Pinkney & Robert D. San Souci & 1996 & $\mathrm{x}$ & & $\mathrm{x}$ & $\mathrm{x}$ & $\mathrm{x}$ & $\mathrm{x}$ \\
\hline The Paperboy & Dav Pilkey & Dav Pilkey & 1997 & $x$ & & & & & \\
\hline The Gardener & David Small & Sarah Stewart & 1998 & & & & & $\mathrm{x}$ & $\mathrm{x}$ \\
\hline Harlem & Christopher Myers & Walter Dean Myers & 1998 & & & $\mathrm{x}$ & $\mathrm{x}$ & $\mathrm{x}$ & $\mathrm{x}$ \\
\hline \begin{tabular}{|l} 
Duke Ellington \\
\end{tabular} & Brian Pinkney & Andrea Davis Pinkney & 1999 & $\mathrm{x}$ & & $\mathrm{x}$ & $\mathrm{x}$ & $\mathbf{x}$ & $\mathrm{x}$ \\
\hline A Child's Calendar & Trina Schart Hyman & John Updike & 2000 & & & $\mathrm{x}$ & & & \\
\hline Martin's Big Words & Bryan Collier & Doreen Rappaport & 2002 & $\mathrm{x}$ & & & $\mathrm{x}$ & $\mathrm{x}$ & $\mathrm{x}$ \\
\hline The Stray Dog & Marc Simont & Marc Simont & 2002 & & & & & $\mathbf{x}$ & \\
\hline Ella Sarah Gets Dressed & Margaret Chodos-Irvine & Margaret Chodos-Irvine & 2004 & & & & $\mathrm{x}$ & & \\
\hline Coming on Home Soon & E. B. Lewis & Jacqueline Woodson & 2005 & & $\mathrm{x}$ & $\mathrm{x}$ & $\mathrm{x}$ & & \\
\hline Knuffle Bunny & Mo Willems & Mo Willems & 2005 & & & & & $\mathbf{x}$ & \\
\hline Rosa & Bryan Collier & Nikki Giovanni & 2006 & & $\mathrm{x}$ & $\mathrm{x}$ & $\mathrm{x}$ & $\mathbf{x}$ & $\mathrm{x}$ \\
\hline Flotsam & David Wiesner & David Wiesner & 2007 & & & $\mathrm{x}$ & & & \\
\hline Moses & Kadir Nelson & Carole Boston Weatherford & 2007 & & $\mathrm{x}$ & $\mathrm{x}$ & $\mathrm{x}$ & $\mathbf{x}$ & $\mathrm{x}$ \\
\hline Henry's Freedom Box & Kadir Nelson & Ellen Levine & 2008 & $\mathrm{x}$ & & $\mathrm{x}$ & $\mathrm{x}$ & $\mathbf{x}$ & $\mathrm{x}$ \\
\hline The Wall & Peter Sis & Peter Sis & 2008 & & & & & $\mathrm{x}$ & \\
\hline All the World & Marla Frazee & Liz Garton Scanlon & 2010 & & & $x$ & & $\mathbf{x}$ & $\mathrm{x}$ \\
\hline \begin{tabular}{|l|} 
Dave the Potter \\
\end{tabular} & Bryan Collier & Laban Carrick & 2011 & $\mathrm{x}$ & & & & $\mathbf{x}$ & \\
\hline Blackout & John Rocco & John Rocco & 2012 & & $\mathrm{x}$ & & $\mathrm{x}$ & & \\
\hline Locomotive & Brian Floca & Brian Floca & 2014 & & & $x$ & & & \\
\hline Last Stop on Market Street & Christian Robinson & Matt DeLaPeña & 2016 & $\mathrm{x}$ & & $x$ & $\mathrm{x}$ & $\mathbf{x}$ & $\mathrm{x}$ \\
\hline Voices of Freedom & Ekua Holmes & Carole Boston Weatherford & 2016 & & $\mathrm{x}$ & $x$ & $\mathrm{x}$ & $\mathbf{x}$ & \\
\hline Trombone Shorty & Bryan Collier & Troy Andrews & 2016 & $\mathrm{x}$ & & $\mathrm{x}$ & & $\mathbf{x}$ & $\mathrm{x}$ \\
\hline
\end{tabular}

Figure 2. Representations of African American, African, Caribbean and Jamaican people in Caldecott winning and honor books, 1992-2016. Data compiled from author's research.

Andy and the Lion was a 1939 honor book written and illustrated by James

Daugherty. This story about an imaginary friendship between a young white boy and a

lion includes a single image of an African American man who is shown running through

a crowd at the circus. The man has dark skin and exaggerated features common to the

stereotypical images of African Americans at the time (Daugherty, 1938).

Abraham Lincoln, the 1940 medal winner written and illustrated by Ingri and

Edgar Parin d'Aulaire, was the second Caldecott title featuring African Americans. In

this biography, the first time we encounter images of African Americans is a two-page 
spread about a slave market. On the left page, interspersed among the text are three small illustrations: one of an African American with a load of fruit on his head larger than himself accompanied by the text "running about with loads on their heads;" one of a crying mammy figure surrounded by young Black children with the text "Negro mothers were weeping for they never knew if they would see their little black babies again when they were sold;" and the third of a small African American woman in a white dress with a white scarf on her head shaking hands with Abe Lincoln. On the right page, is a black and white illustration of a raised platform with a white auctioneer, a barefoot African American woman and four African American children. All of the enslaved people are shown with nondescript features, very black skin and bulging white eyes. The text on the platform reads "Slaves, Horses and Other Cattle Sold." White men in the foreground are shown raising their hands while more African Americans stand behind the platform with the cattle (see Figure 3). The next image of African Americans is a street scene with Abraham Lincoln, who is holding the hand of a white boy, as dozens of African Americans follow, gather and bow around him (see Figure 3, left-hand image).

In December of 2015, a new edition of this book was released with several revisions to the text and illustrations. Most notably with regard to African American content, the scene of the auction block has been revised to lighten the Black peoples' skin, give them recognizable features and realistic eyes; most are wearing scarves or hats in lieu of the knotted hair in the original illustration (see Figure 3, right-hand image.) Again, in the revised street scene illustration, the African Americans' skin is lighter and their faces more discernible (see Figure 4). As a result of the changes, the faces of some 
of the enslaved people are distorted and unusual in the updated images, which is not necessarily an improvement, so any effort to create a benefit may be moot. Be that as it may, the original version is still readily available in local libraries. Text from the original version when Lincoln responds to an enslaved person who throws himself at Lincoln's feet and cries, "Here is our savior" has been revised to read, "Don't kneel to me. You must kneel to God only and thank Him for your freedom.” It previously stated that Lincoln had responded with "Glory, glory hallelujah” (d'Aulaire, I.P. and E.P. 1939, 2015). 


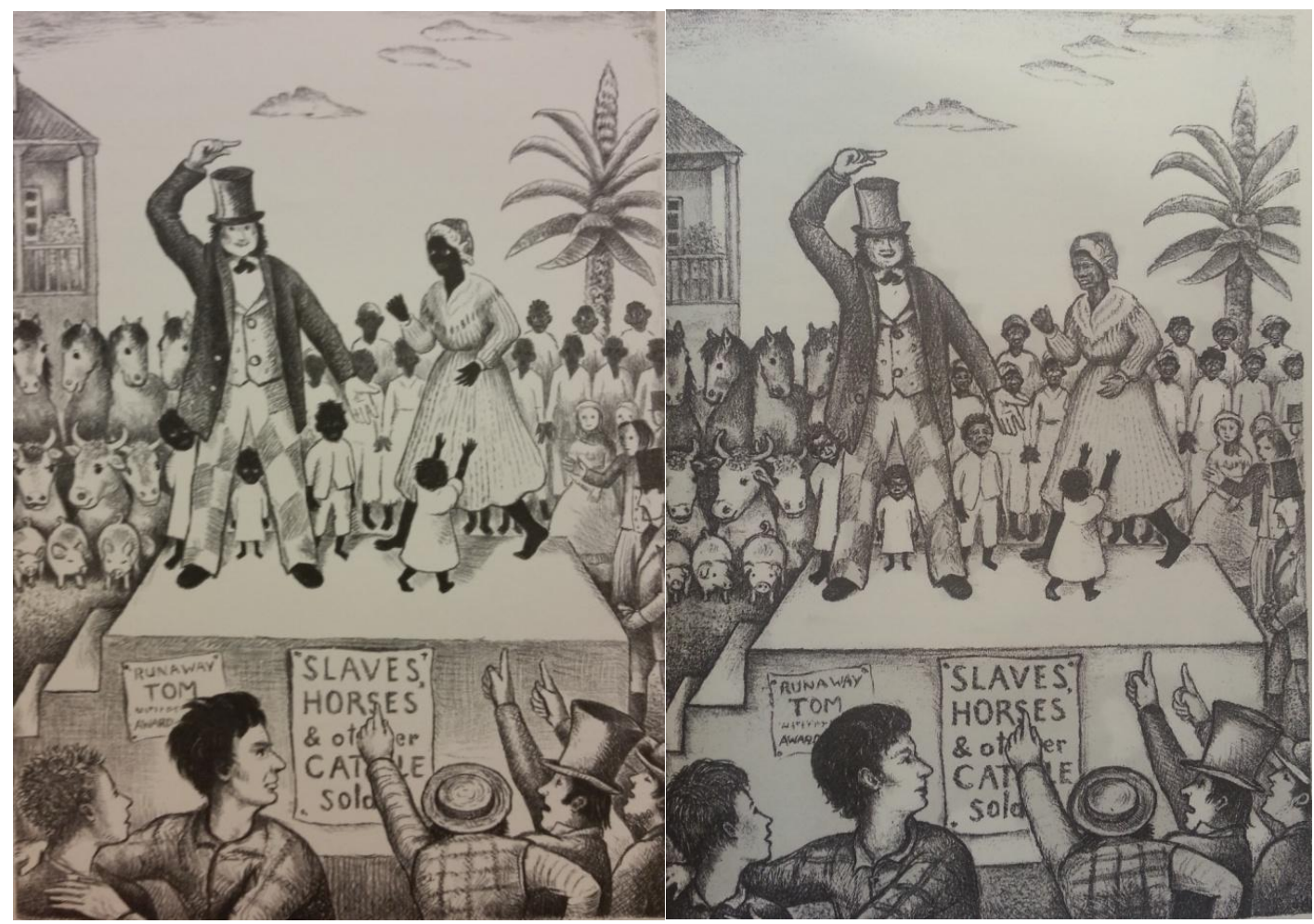

Figure 3. First images of African Americans in the 1939 biography of Abraham Lincoln. The image on the left is from the 1957 edition of the book, and the one on the right is from the 2015 edition. Reprinted from Abraham Lincoln, by I. and E.P. d'Aulaire, 1957, Garden City, NY: Doubleday \& Company. (Original work published 1939.) The image from the 1957 edition is reproduced by permission of the copyright holders, Per Ola d'Aulaire and Nils Daulaire. The image from the 2015 edition is reproduced by permission of Beautiful Feet Books, Inc. 

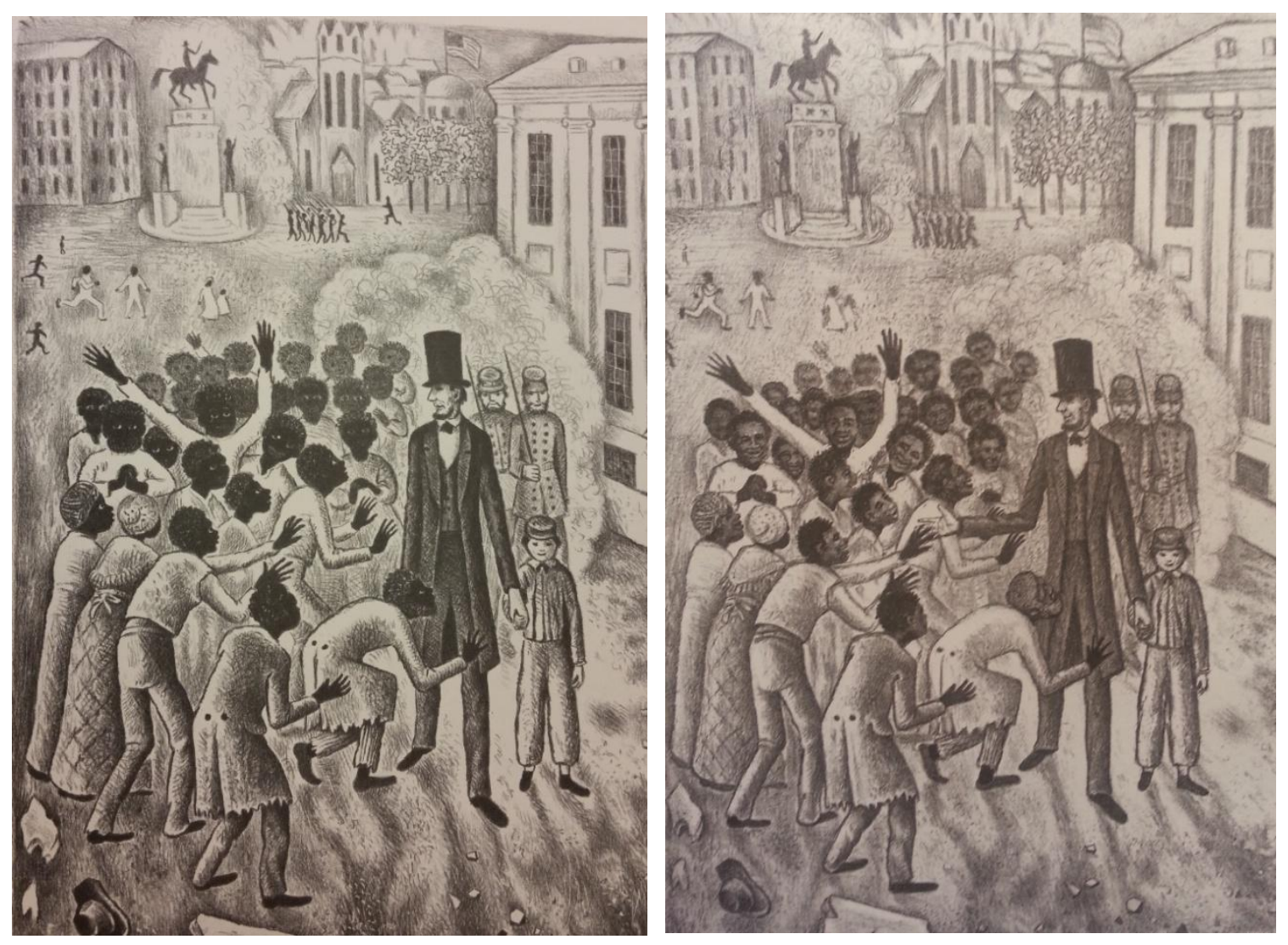

Figure 4. Images from different editions of the Lincoln biography. The image on the left is from the 1957 edition, and the one on the right is from the 2015 edition. Reprinted from Abraham Lincoln, by I. P. d'Aulaire and E.P. d'Aulaire, 1957, Garden City, NY: Doubleday \& Company. (Original work published 1939). The image from the 1957 edition is reproduced by permission of the copyright holders, Per Ola d'Aulaire and Nils Daulaire. The image from the 2015 edition is reproduced by permission of Beautiful Feet Books, Inc.

They Were Strong and Good, written and illustrated by Robert Lawson, won the gold medal in 1941. The first appearance of a Black person in this book is a young Caribbean boy shown carrying two monkeys and balancing sticks on his head. The second is of a woman chasing two American Indians from a house with a broom. She is wearing mammy style clothing often used to portray African American women at the 
time. No mention of her is made in the text. The third image is of an African American boy in worn clothing watching as a preacher goes by on his horse. Again, he is not mentioned in the text. The fourth time we see an African American person, he is shown out hunting with the author's grandfather who "had two dogs and a colored boy." His name, Dick, is mentioned in the text contrasted against the dogs' names: Sextus Hostilius and Numa Pompilius. The next time we see an African American is accompanying the narrative that the grandfather is going off to fight the Yankees. In this image we see the African American boy and the mammy figure previously depicted with their faces buried in their hands. Accompanying such text, the implication is that they are weeping because they are so sad their master is leaving. The final image of an African American is of a young man riding through town on a horse. The accompanying text, "the country all about was filled with deserters and runaway slaves," would suggest that he is one of the escapees (Lawson, 1940). Revisions to some of the text in this book were made in 1994 at which time the text accompanying the image of the hunters was changed to "When my father was very young he had a Negro slave and two dogs. The dogs were named Sextus Hostilius and Numa Pompilius. The Negro boy was just my father's age and his name was Dick. He and my father and the two hound dogs used to hunt all day long" (Sieruta, 2009).

In An American $A B C$, the 1942 honor book written and illustrated by Maud and Miska Petersham, the single image of an African American in is in the illustration for " $\mathrm{G}$ is for George Washington." In this picture, young George Washington is shown on a horse while a young African American boy with exaggerated facial features watches from 
a fence surrounded by Washington's hat, jacket, and horse tack. Perhaps he is intended to be Washington's slave or stable hand (Petersham, 1941).

A book with a biblical focus, Small Rain: Verses from the Bible, illustrated by Elizabeth Orton Jones and written by Jessie Orton Jones won an honor award in 1944. The illustrations feature an African American boy in five of the images as well as the cover (albeit the cover is the back of his head and the cover image is repeated from one of the internal images). Accompanying assorted verses from the Bible, he is featured playing with the other children, wearing similar clothing and with similar features (Jones, 1943). African American librarian Charlemae Rollins stated that the illustrations would "help portray children of all kinds doing things happily together" (Rollins, 1950) and this title appears later in an article with recommended books about Black children. The author called it "truly delightful" and appreciated there were images of "children of all major biological and religious groups doing together all of the things children do" (Boyd, 1958).

In Prayer for a Child, the 1945 medal winner illustrated by Elizabeth Orton Jones and written by Rachel Field several Black faces are shown in the crowd illustrating the other children "far and near" from the primary character's prayer (Field, 1944). Charlemae Rollins felt that "any little Negro child will be proud to identify himself with the appealing children drawn by Elizabeth Orton Jones" (Rollins, 1950).

The 1946 gold medal winner, The Rooster Crows: A Book of American Rhymes and Jingles, written and illustrated by Maud and Miska Petersham was the third of the Caldecott titles to ultimately be revised due to its negative portrayal of African 
Americans (Peterhsam, 1945). The original publication included two pages featuring African American boys with "great buniony feet, coal black skin, and bulging eyes (in the distance, a dilapidated cabin with a black, gun-toting, barefoot adult)" (Larrick, 1965). This book of rhymes became the "focus of controversy when the NAACP contended that the book portrayed Blacks in an unfavorable light." In response, the publisher revised the text in 1963 removing the Black content altogether, rearranging the rhymes featuring white people, and resulting in removing all African American representation from a book proclaiming to be a book of American rhymes (Pescosolido, et al., 1997).

Sing in Praise, a 1947 honor book illustrated by Marjorie Torrey and written by Opal Wheeler, features a page of multi-racial faces among which one African American boy is included. In the image, he is shown leaning against and gazing at Jesus while Jesus' arm rests on his shoulder (Wheeler, 1946).

Henry Fisherman, a 1950 honor book written and illustrated by Marcia Brown, is the first to feature a Black primary character. This is the story of a young boy on a Caribbean island who longs to be a fisherman like his father and other men in his family. Brown tells the story of the boy's relaxed days on the isle and his family's activities and his ultimate success with fishing. Interestingly, the book jacket text states the tale is of an American boy but nothing in the narrative indicates this is the case. An author's note indicates she was inspired to tell this story after spending summers on the St. Thomas (Brown, 1949).

Dick Whittington and his Cat, a 1951 honor book also written and illustrated by Marcia Brown is the story of young Dick whose cat is offered to a Moorish king to rid the 
palace of mice. The king, queen, and other Africans are depicted gratefully enjoying the cat's presence as he helps to remove the pesky rodents. The king gratefully sends treasure back to Dick as payment for the cat (Brown, 1950).

Another 1951 honor book, If I Ran the Zoo, written and illustrated by Theodor Seuss Geisel, is the story of a young Gerald McGrew who re-imagines the zoo as it would appear if he were in charge. As he travels around the world gathering unusual creatures, the reader sees Africans portrayed as caricatures of "Bushmen," or San people (Seuss, 1950). These images remain the same in today's editions.

Fly High, Fly Low, a 1958 honor book written and illustrated by Don Freeman, is the story of a pigeon's misplaced nest and includes an African American man who keeps it intact en route to its new location. The man is depicted carrying out his workaday activities while caring and concerned about the pigeon's home (Freeman, 1957).

A Snowy Day, which won a gold medal in 1963, was the first book to feature an African American as the primary character. A young African American boy, Peter, steps out of his house and into freshly fallen snow and the reader follows him as he explores and plays in his neighborhood. Ezra Jack Keats, a white Jewish man, was raised in inner city New York during the Depression and attributes most of his illustrations to this experience (Keats, 1962). Of his decision to illustrate an African American child he said, "My book would have him there simply because he should have been there all along" (Nahson, 2011). A great deal of controversy has revolved around this seemingly simple book. Besides the Caldecott committee, some contemporary reviewers praised its content. Among them was African American librarian Augusta Baker who said "The author-artist 
has made a beautiful picture book about the fun which a small boy has in the deep soft snow" (Baker, 1963). Langston Hughes found the book “"perfectly charming' and lamented that he did not have "grandchildren to give it to"' (Nahson, 2011). Others disapproved because the book failed to mention that Peter is Black (Larrick, 1965) and one critic was "skeptical of what he believed was Keats's attempt to humanize and normalize a black child by depicting him as racially neutral, enjoying 'snow and whiteness as well as everyone else"' (Nahson, 2011). Retrospectively, in 2014, M. Tyler Sassner looked back on The Snowy Day and its reception in the Civil Rights Era with a review of the Keats Archive at the de Grummond Children's Literature Collection. He found there much support from Harlem Renaissance leaders such as Langston Hughes, Ellen Tarry, Grace Nail Johnson and Charlemae Hill Rollins and resistance from Black Power Movement leaders who felt "whites can only give a white interpretation of blacks" (Sassner, 2014). A look at the perspective of authors and illustrators today find many from Sherman Alexie (Nahson, 2011) to Katheryn Russell-Brown (Lyons, 2015), Sean Qualls (Tate, 2008), Zetta Elliott (Tate, 2009) and Bryan Collier (Tate, 2012) - who found great inspiration in Ezra Jack Keats's work.

A 1969 honor book, Why the Sun and Moon Live in the Sky, was illustrated by Blair Lent and written by Elphinstone Dayrell. This African folktale of how the sun and moon came to live in the sky is told through illustrations featuring Africans dressed as the moon, sun, water, and assorted animals. Source notes indicate this story was heard from the Efik-Ibibio people in Southwestern Nigeria but that the artist was influenced by "all Africa" (Dayrell, 1968). 
Goggles, a 1970 honor book written and illustrated by Ezra Jack Keats, was his second Caldecott title. This is another story starring the African American boy we met in A Snowy Day. This time Peter and a friend find some motorcycle goggles they're very excited to play with but before they get to enjoy them, they're bullied by the big boys in the neighborhood, ultimately getting away safely with their treasure (Keats, 1969).

A Story A Story was the 1971 medal winner written and illustrated by Gail E. Haley. Inspired by time in the Caribbean, here she retells an African story about Ananse and how he manages to get the world's stories from the sky god, and make it possible for humans to tell stories. Haley studied African folklore to prepare to tell this tale and used woodcut illustrations throughout (Haley, 1970).

Moja Means One: Swahili Counting Book was a 1972 honor book and the first of two illustrated by Tom Feelings and written by Muriel Feelings, an African American couple. With this award, came the first male African American illustrator and first female African American author to receive a Caldecott honor. The book features numbers 1-10 in Swahili with a two-page black and white illustration accompanying a scene from East African life (Feelings, 1971).

Jambo Means Hello: Swahili Alphabet Book was a 1975 honor book, the second illustrated by Tom Feelings and written by Muriel Feelings, and a companion book to the preceding Moja Means One. Featuring 24 letters, one for each of letter of the Swahili alphabet, children are introduced to words representing each letter along with vivid black and white illustrations in the same style as their previous title (Feelings, 1974). 
Why Mosquitoes Buzz in People's Ears was the 1976 medal winner illustrated by Leo and Diane Dillion and written by Verna Aardema. With this win, Leo Dillon became the first African American to be awarded the gold medal for his work. Dillon's artistic partner, and wife, Diane, was white. Cause and effect are the theme of this West African tale (Aardema, 1975).

Illustrators Leo and Diane Dillon are back with another gold medal winner in 1977's Ashanti to Zulu: African Traditions, which was written by Margaret Musgrove. Through exhaustive research the author studied many African cultures. In this book, she focuses on one tribe per letter of the alphabet. Using watercolor, pastels and acrylics, the Dillons attempt to bring the most information to the reader by including one man, one woman, one child, living quarters, local animal and local artifact in their images representing each tribe (Musgrove, 1976).

The Way to Start a Day illustrated by Peter Parnall and written by Byrd Baylor won a silver medal in 1979. In this story of multicultural people singing a morning greeting, Baylor includes images for drumming "sunrise songs in the Congo" and Egyptians proclaiming "the only sound at dawn should be the sound of songs that please the morning sun." Parnall chooses predominantly yellow, turquoise and green to emphasize different parts of the landscape, with pink and turquoise as the primary colors for peoples' clothing (Baylor, 1978).

Ben's Trumpet was a 1980 honor book written and illustrated by Rachel Isadora which tells the story of an aspiring African American jazz musician accompanied by black and white illustrations (Isadora, 1979). 
Previous winner Marcia Brown received another gold medal for her illustrations in Shadow in 1983. Shadow is the translated work of Blaise Cendrars, a French poet who traveled extensively in Africa, who wrote this poem in an effort to capture the African experience of shadow (Brown, 1982). However, because this book depicts Africans as people distant from modernity and instead part of the "fast-vanishing Africa," the book was met with severe criticism for "negative and destructive stereotypes about Africa and black people" and concern that "Black children will transfer to themselves a primitive and denigrating image" (Howard, 1983).

In the same year, A Chair for My Mother author and illustrator Vera Williams makes her first appearance on the Caldecott list. In this story about a young girl whose family loses their home to a fire and then saves for a new chair, an African American woman is depicted working in a restaurant alongside the protagonist's white mother (Williams, 1982).

Ten, Nine, Eight, a 1984 honor book written and illustrated by Molly Bang, is the first time we see a female African American as the primary character in a Caldecott title. This full color story counts down from ten to one as a little girl gets ready for bedtime with help from her daddy (Bang, 1983).

The Polar Express was the 1986 medal winner written and illustrated by Chris Van Allsburg. There is a single image of an African American child who is shown engaged in conversation with a white child on a train (Van Allsburg, 1985).

The Village of Round and Square Houses was a 1987 honor book written and illustrated by Ann Grifalconi, a white woman. It is the tale of a remote village in the hills 
of the Camaroons in Central African where the women live in round houses and the men in square houses following a volcanic explosion that leaves only two buildings standing (Grifalconi, 1986).

Written and illustrated by John Steptoe, Mufaro's Beautiful Daughters: An African Tale, won an honor award in 1988. It was also the Coretta Scott King Illustrator Award winner that year. Steptoe was inspired by a folktale collected from the Zimbabwe region in 1895 to create a modern tale of two sisters, one evil and one kind, who are vying for marriage to the king (Steptoe, 1987).

Mirandy and Brother Wind was a 1989 honor book illustrated by Jerry Pinkney and written by Patricia C. McKissack which also won a Coretta Scott King Illustrator Award. Featuring a young Southern African American girl who tries to capture the wind to help ensure she wins a dance contest, Pinkney adds to the tale with full color watercolor images (McKissack, 1988).

A 1990 book, The Talking Eggs: A Folktale from the American South, was also illustrated by Jerry Pinkney and in addition to a Caldecott honor received a Coretta Scott King Illustrator Honor award. Written by Robert D. San Souci, it is a retelling of a Southern folktale of two sisters, one lazy and one hard-working. With pencils, colored pencils and watercolor, Pinkney brings the story to life (San Souci, 1989).

“More, More, More,” Said the Baby: Three Love Stories was a 1991 honor book written and illustrated by Vera B. Williams. Illustrated with gouache paintings, this book includes three little stories about babies being loved by different people in their lives, one of which is an African American baby with their white grandma (Williams, 1990). 
Tar Beach, a 1992 honor book written and illustrated by Faith Ringgold, an African American woman, also won the Coretta Scott King Illustrator Award. The story features young Cassie, who takes flight from "tar beach," her family's apartment rooftop. Acrylic paintings show Cassie flying over the city claiming everything in sight for her own (Ringgold, 1991).

Illustrated by Carole Byard and written by Sherley Anne Williams, Working Cotton was named a 1993 honor book as well as a Coretta Scott King Illustrator Honor title. With acrylic illustrations, Byard helps relate this story of a young African American girl and her family on a central California cotton plantation (Williams, 1992).

Grandfather's Journey, the 1994 medal winner written and illustrated by Allen Say is the story of the author's grandfather's journey to America. A single image of an African American man accompanies the text "He shook hands with black men and white men, yellow men and red men" (Say, 1993).

Yo! Yes?, named a 1994 honor book, was illustrated by Chris Raschka and edited by Richard Jackson. Watercolor and charcoal pencil illustrate this sparsely worded story of two boys, one African American and one white, who meet on the street and quickly become friends. In fact, the Library of Congress catalog description summarizes this book as "Two lonely characters, one black and one white, meet on the street and become friends" (Raschka, 1993). However, Raschka himself stated that it was his "intent to portray an interracial situation while noting that the characters were deliberately drawn ambiguously to allow for 'depth and resonance' with more people" (Pescosolido, et al. 1997). 
Smoky Night was the 1995 medal winner illustrated by David Diaz and written by Eve Bunting. A young African American boy and his mother need to escape their burning building following the riots in Los Angeles which followed the verdict in the Rodney King case. The features of the many races are quite similar while the Latino and Korean people appear to have lighter skin. Diaz used a variety of collage materials to create visually strong images. This story with an African American male primary character is told by a Latino male illustrator and white female author (Bunting, 1994). The language, from a white woman's perspective, does not appear to have the benefit of the African American experience. One reviewer stated "Rather, in Bunting's trivialized interpretation of the South Central rebellion, there's no racism, no poverty, no injusticejust angry people who enjoy looting and can take a lesson in getting along from a couple of cats." Using the child's voice, she purports, gives Bunting leave to avoid having to explore the complex social issues surrounding the riots (Slapin, 2012). Still others found the violence inappropriate for a picture book audience. Yet noted book reviewer Zena Sutherland opined that television violence children are exposed to every day is far worse and that he "can't see the violence of an actual event is going to harm them" (Sutherland, 1997).

John Henry, a 1995 honor book, illustrated by Jerry Pinkney and written by Julius Lester is the story of African American folk hero John Henry. Inspired by the song of the same name and abundant folklore, Pinkney weaves the visual tale with vivid watercolor images (Lester, 1994). 
Swamp Angel, another 1995 honor book, was illustrated by Paul O. Zelinsky and written by Anne Isaacs. This "tall tale" features a white female protagonist with three African Americans in background images dancing, playing an instrument and riding in a boat (Isaacs, 1994).

Zin! Zin! Zin! A Violin was a 1996 honor book illustrated by Marjorie Priceman and written by Lloyd Moss. An African American woman is featured in this counting book starring classical music instruments (Moss, 1995).

The Faithful Friend, a 1996 honor book illustrated by Brian Pinkney and written by Robert D. San Souci, is the retelling of a tale from the French West Indies featuring several Black characters from various regions. The illustrator also won a Coretta Scott King Illustrator Honor award (San Souci, 1995).

A 1997 honor book, The Paperboy, was written and illustrated by Dav Pilkey. Illustrated in watercolor and India ink, this contemporary story features a young African American paperboy rising at dawn and going about the business of delivering the neighborhood's newspapers (Pilkey, 1996).

The Gardener was a 1998 honor book illustrated by David Small and written by Sarah Stewart. This story of a young white girl who travels to the city to stay with her uncle after his father loses his job features a helpful and loving African American couple. The couple, who appear to work for her uncle, help the girl create a stunning rooftop garden (Stewart, 1997).

A 1998 honor book, Harlem, was illustrated by Christopher Myers and written by Walter Dean Myers and also won a Coretta Scott King Illustrator Honor. This rhythmic 
poem of the story of the African American experience in Harlem, incorporating references to Africa, Sugar Ray, Langston Hughes, Martin Luther King, Jr., the Cotton Club, and more is illustrated with bold collage, ink and gouache and features a multitude of African American characters (Myers, 1997).

Duke Ellington: The Piano Prince and His Orchestra received a Caldecott honor award in 1999 as well as a Coretta Scott King Illustrator Honor. Illustrated by Brian Pinkney and written by Andrea Davis Pinkney, the story of Duke Ellington is told accompanied with vibrant images created using a scratchboard technique (Pinkney, 1998).

An honor award was received for $A$ Child's Calendar in 2000. Illustrated by Trina Schart Hyman and written by John Updike, this series of poems highlighting a child's experiences from January through December features several images of African Americans including an African American father, white mother, and their biracial children (Updike, 1999).

Martin's Big Words: The Life of Dr. Martin Luther King was a 2002 honor book illustrated by Brian Collier and written by Doreen Rappaport which also won the Coretta Scott King Illustrator Honor award. This picture book biography of Martin Luther King, Jr. was illustrated in Collier's signature watercolor and cut paper collage (Rappaport, 2001).

The Stray Dog, a 2002 honor book written and illustrated by Marc Simont, about a white family hoping to rescue a stray dog includes images of three African Americans in park scenes (Simont, 2001). 
Ella Sarah Gets Dressed is a 2004 honor book written and illustrated by Margaret Chodos-Irvine. In this story about Ella Sarah getting dressed, friends show up at the end, one of whom is an African American girl who is featured with the protagonist and their friends at a tea party (Chodos-Irvine, 2003).

Coming on Home Soon, illustrated by E.B. Lewis and written by Jacqueline Woodson, received an honor award in 2005. White's watercolor images bring life to Woodson's tale of a WWII era African American daughter whose mom who finds work in Chicago and needs to leave her with her grandmother for a while (Woodson, 2004).

Knuffle Bunny, a 2005 honor book written and illustrated by Mo Willems, features an animated African American male in the background as the family runs down a New York City street (Willems, 2004).

Rosa, a 2006 honor book illustrated by Bryan Collier and written by Nikki Giovanni, was also the Coretta Scott King Illustrator Award winner. Illustrated with watercolor and collage Collier aids Giovanni's retelling of the time celebrated Civil Rights activist Rosa Parks refused to give her bus seat to a white man (Giovanni, 2005).

Flotsam, the 2007 medal winner, was written and illustrated by David Wiesner. In this wordless story vibrant watercolor images tell the tale of a camera washing up on shores around the world where the receiving child takes a photo and tosses it back. Two of the images of children are Black boys (Wiesner, 2006).

Moses: When Harriet Tubman Led Her People to Freedom was 2007 honor book illustrated by Kadir Nelson and written by Carole Boston Weatherford which also won the King Illustrator Award. In Moses, Kadir Nelson's vibrant images accompany the 
author's fictional tale of Tubman's spiritual journey compelling her movements on the Underground Railroad (Weatherford, 2006).

Henry's Freedom Box: A True Story from the Underground Railroad is a 2008 honor book illustrated by Kadir Nelson and written by Ellen Levine. Nelson's second honor title in as many years, Henry's Freedom Box relates the story of an enslaved man who, after suffering horrific loss, gains his freedom by having himself mailed to a free state (Levine, 2007).

The Wall: Growing Up Behind the Iron Curtain was a 2008 honor book written and illustrated by Peter Sis. This picture book autobiography includes text from his original journal entries. Surrounding those entries are a number of iconic photos from pop culture of the time, one of which is African American Jimi Hendrix (Sis, 2007).

All the World, a 2010 honor book illustrated by Marla Frazee and written by Liz Garton Scanlon, includes several families interacting with the world around them. Frazee has included an African American father, white mother, and their biracial children among them as well as a Black father and baby (Scanlon, 2009).

Dave the Potter: Artist, Poet, Slave, a 2011 honor book written by Laban Carrick and illustrated by Bryan Collier brought Collier his third Caldecott title as well as another Coretta Scott King Illustrator Award. Using watercolor collage, Collier brings Carrick's poetic homage to "Dave the Potter" to life (Carrick, 2010).

Blackout was a 2012 honor book written and illustrated by John Rocco. This tale of a family's night of amusement when their power goes out includes an African American mom, white father, and their biracial children (Rocco, 2011). 
The 2014 gold medal winner, Locomotive, was written and illustrated by Brian Floca. In this book about the first transcontinental railroad trip, there is an African American shown working beside two white men building the rail lines and another image in which an African American porter is placing some luggage overhead (Floca, 2013).

In 2016, of the medal winner and four honor books, three featured African Americans as primary characters. Two were authored by African Americans, one female and one male. One was written by a Latino man. Two were illustrated by African American men and one by an African American woman. The medal winner, Finding Winnie, was illustrated by Sophie Blackall and written by Lindsay Mattick, both white women. Controversy ensued as some people raved about the excellent choices, and appreciated "the diversity reflected in the selections" while others raged about the choices, blaming the committee for deciding to "promote diversity over quality" (Robinson, 2016).

Last Stop on Market Street, which was illustrated by Christian Robinson and written by Matt de la Peña, received an honor award. This is the story of young African American protagonist $\mathbf{C J}$ and his experience on a bus ride he takes across town with his grandmother. Using digital manipulation, acrylic paint, and collage, Robinson fills the pages with multiple African American characters including the bus driver, other passengers, and people on the street (de la Peña, 2015). Last Stop on Market Street also won the Newbery gold medal in 2016.

Voice of Freedom: Fannie Lou Hamer Spirit of the Civil Rights Movement, illustrated by Ekua Holmes and written by Carole Boston Weatherford, also received an 
honor award in 2016. Told in verse, this is the story of African American Civil Rights activist, Fannie Lou Hamer, and the numerous efforts she made in the fight for equality. It is illustrated by Ekua Holmes in full color collage (Weatherford, 2015).

The second autobiography to appear in the Caldecott canon is Trombone Shorty, which was illustrated by Bryan Collier and written by Troy "Trombone Shorty" Andrews. This picture book tells the tale of contemporary African American jazz musician, Trombone Shorty, from his childhood to the successful music career he enjoys today. Illustrated with Collier's pen and ink, watercolor and collage images, the vibrant tale comes to life (Andrews, 2015).

Black people have been represented in a myriad of ways in the Caldecott titles over the decades. The majority of the portrayals are historic, take place in another country, or are African or African American folktales. Interestingly, Abraham Lincoln, They Were Strong and Good and The Rooster Crows have all been revised since their original publication to alter racist and/or stereotyped images or language. Very few of the Caldecott titles place the African American in contemporary times and, as Larrick (1963) stated "it is no small comfort to read of the Negro slave who smilingly served his white master" to a present day child. Of the 62 titles which include a Black character, only 21 include an African American character in a setting contemporaneous with the date of publication and only two of those were medal winners, both in books contentious at the time of publication and still today: A Snowy Day and Smoky Night. Of those 21 featuring an African American in a contemporary setting, 14 are the primary character. While 62 books is significant as $19 \%$ of the books compared to the 2014 African 
American population estimate of $13.6 \%$, it is important to note how African Americans have been depicted in them, as detailed above. Inasmuch as only 21 books portray a contemporary setting, it reduces the total in which a child could potentially recognize themselves to just above $6 \%$.

\section{American Indian Representation}

Of the 332 Caldecott titles from 1938-2016, 6\% (21 titles) included images of American Indians in some capacity: seven featured male American Indians as primary characters and four featured females; 13 featured males and nine included females as secondary characters; and ten featured males and six females as background characters (see Figure 5). Ten of the 21 titles, or 3\%, featuring American Indians were about American Indians only.

\begin{tabular}{|c|c|c|c|c|c|c|c|c|c|}
\hline \multirow{2}{*}{$\begin{array}{l}\text { Title } \\
\text { Abraham Lincoln }\end{array}$} & Illustrator & Author & \multicolumn{2}{|l|}{ Year/ } & & & & & \\
\hline & |Ingri \& Edgar Parin d'Aulaire & Ingri \& Edgar Parin d'Aulaire & 1940 & & & 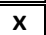 & & & \\
\hline They Were Strong and Good & Robert Lawson & Robert Lawson & 1941 & & & $\mathbf{x}$ & $\mathbf{x}$ & & \\
\hline An American ABC & Maud \& Miska Petersham & Maud \& Miska Petersham & 1942 & & & $\mathbf{x}$ & & $x$ & \\
\hline In My Mother's House & Velino Herrera & Ann Nolan Clark & 1942 & & $\mathbf{x}$ & & $\mathbf{x}$ & $\mathbf{x}$ & $\mathbf{x}$ \\
\hline Paddle-to-the-Sea & Holling C. Holling & Holling C. Holling & 1942 & $\mathbf{x}$ & & & & $\mathbf{x}$ & \\
\hline The Mighty Hunter & Berta + Elmer Hader & Berta + Elber Hader & 1944 & $\mathbf{x}$ & & & $\mathbf{x}$ & & \\
\hline Prayer for a Child & Elizabeth Orton Jones & Rachel Field & 1945 & & & & & $\mathbf{x}$ & $\mathbf{x}$ \\
\hline The Thanksgiving Story & Helen Sewell & Alice Dalgiesh & 1955 & & & $\mathbf{x}$ & & & \\
\hline Houses from the Sea & Adrienne Adams & Alice E. Goudey & 1960 & & & & & $\mathbf{x}$ & \\
\hline The Sun is a Golden Earring & Bernarda Bryson & Natalia M. Belting & 1963 & & & $\mathbf{x}$ & & & \\
\hline \begin{tabular}{|l} 
The Angry Moon \\
\end{tabular} & Blair Lent & William Sleator & 1971 & $\mathbf{x}$ & $\mathbf{x}$ & $\mathbf{x}$ & $\mathbf{x}$ & & \\
\hline When Clay Sings & Tom Bahti & Byrd Baylor & 1973 & & & $\mathbf{x}$ & $\mathbf{x}$ & $\mathbf{x}$ & $x$ \\
\hline Arrow to the Sun & Gerald McDermott & Gerald McDermott & 1975 & $\mathbf{x}$ & $\mathbf{x}$ & $\mathbf{x}$ & $\mathbf{x}$ & & \\
\hline The Desert is Theirs & Peter Parnall & Byrd Baylor & 1976 & & & & & & $x$ \\
\hline Hawk, I'm Your Brother & Peter Parnall & Byrd Baylor & 1977 & $\mathbf{x}$ & & $\mathbf{x}$ & & & \\
\hline The Girl Who Loved Wild Horses & Paul Goble & Paul Goble & 1979 & & $\mathbf{x}$ & $\mathbf{x}$ & $\mathbf{x}$ & $x$ & $x$ \\
\hline The Way to Start a Day & Peter Parnall & Byrd Baylor & 1979 & & & $\mathbf{x}$ & $\mathbf{x}$ & & \\
\hline Where the Buffaloes Begin & Stephen Gammell & Olaf Baker & 1982 & $\mathbf{x}$ & & & & $x$ & \\
\hline \begin{tabular}{|l|} 
Grandfather's Journey \\
\end{tabular} & Allen Say & Allen Say & 1994 & & & $\mathbf{x}$ & & & \\
\hline Raven & Gerald McDermott & Gerald McDermott & 1994 & $\mathbf{x}$ & & $\mathbf{x}$ & $\mathbf{x}$ & $\mathbf{x}$ & $\mathrm{x}$ \\
\hline
\end{tabular}

Figure 5. Caldecott titles from 1938 to 2016 including images of American Indians. Data compiled from author's research. 
The first appearance of American Indians in the Caldecott titles was in the 1940 medal-winning Abraham Lincoln, a biography of the $16^{\text {th }}$ president, by Ingri and Edgar Parin d'Aulaire (d'Aulaire, 1957). Among the illustrations, on a two page spread, one sees a small caricature of a dancing American Indian man in the upper left hand corner across from a full page illustration of Abraham Lincoln with Chief Black Hawk, who is shown hunkered down behind him. In honor of the $75^{\text {th }}$ anniversary of its publication, a reprint was issued with a number of revisions. In particular, Chief Black Hawk's bent knees (creating the appearance of cowering behind Lincoln) have been removed so that he appears to be standing straight. In addition, Chief Black Hawk's hand is now on the hilt of Abraham Lincoln's sword whereas previously it was on his waist (see Figure 6). Slight changes to the text have been made as well. Debbie Reese, a Nambe Pueblo Indian woman who runs the blog American Indians in Children's Literature, states that simply changing Chief Black Hawk from cowering to standing erect does nothing to correct the "white savior theme" (Reese, 2016). She takes further exception to an illustration of toddler Abraham Lincoln, where the accompanying text states that "Abe is solemn like a little papoose," perpetuating the stereotype of the stoic American Indian (Reese, 2016). 

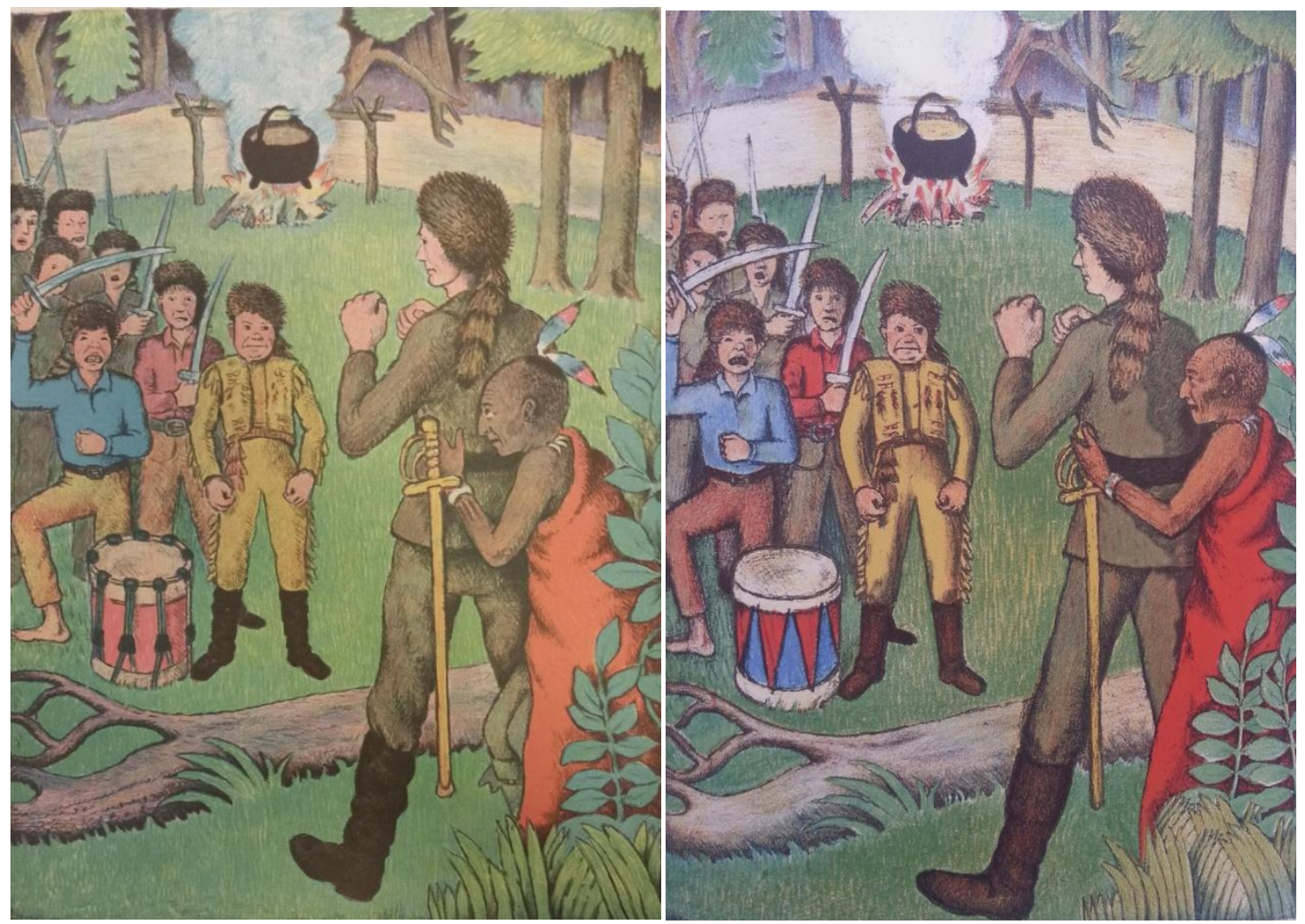

Figure 6. Images of Abraham Lincoln and Chief Blackhawk from different editions of the d'Aulaires' biography of Abraham Lincoln. The image on the left is from the 1957 edition of the book, and the one on the right is from the 2015 edition. Reprinted from Abraham Lincoln, by I. P. d'Aulaire and E .P. d'Aulaire, 1957, Garden City, NY: Doubleday. (Original work published 1939). The image from the 1957 edition is reproduced by permission of the copyright holders, Per Ola d'Aulaire and Nils Daulaire. The image from the 2015 edition is reproduced by permission of Beautiful Feet Books, Inc.

The following year we see American Indians in They Were Strong and Good, written and illustrated by Robert Lawson, which won the gold medal in 1941. The sole image of American Indians features a man and woman running from a house chased by an African American woman wielding a broom along with the textual information that the author's grandmother did not like the "Indians" who "would stalk into the kitchen without knocking and...not leave until my mother's mother gave them something to eat" 
(Lawson, 1966). Interestingly, in another case of editing a reprint, the sparse text accompanying this image was revised in 1994 to remove text previously describing the Indians in the image as "tame ones" (Reese, 2011).

1942 brought us three Caldecott honor books featuring American Indians in some capacity. In An American ABC, author-illustrator team Maud and Miska Petersham depict American Indians on pages for the letters J (Jamestown), K (Knickerbocker), R (Redskins), and T (Thanksgiving). For Jamestown, Captain John Smith is illustrated engaged in finding "a way to get corn from the unfriendly Indians" for hungry colonists (Petersham, 1941). As Smith is depicted holding blue cloth out to an American Indian man standing beside a bucket of corn, one can deduce from the illustration that one way to get corn was to trade fabric. The American Indian man is wearing moccasins, a loin cloth, an arrow and quiver, and single feather on his head. Knickerbocker referenced a Dutch family who settled on Manhattan and whose family members are engaged in trade with an Indian man. The colonists depicted are a fully clothed boy and girl holding a piece of blue cloth while the Indian man shown is wearing moccasins, leather pants, and two feathers in his short Mohawk while carrying an armful of furs. For " $\mathrm{R}$ is for Redskins, the first real Americans," the illustrators chose to depict Squanto, "one of the friendly redskins" teaching a hungry Pilgrim child "how to tread the stream for eels." Finally, the pages dedicated to " $\mathrm{T}$ is for Thanksgiving" feature American Indian men wearing single pieces of cloth with feathers in their hair.

In My Mother's House illustrated by Velino Herrera and written by Ann Nolan Clark, features American Indians in both full color and black and white illustrations. 
Included are images of their homes, farms, and surrounding desert and mountain terrain. People are shown plowing, preparing food, dancing, and in ceremony. The people's faces are left white in the black and white illustrations and are brown in the full color images (Clark, 1969). While Velino Herrera, a Pueblo Indian man (Benes, 2004), has the distinction of being the only American Indian illustrator-or author-of a Caldecott book, Ann Nolan Clark was a white woman who believed that the stories of American Indian children needed to be told (Kunitz, 1951).

In the third honor book of 1942, Paddle-to-the-Sea, written and illustrated by Holling Clancy Holling, an American Indian boy creates a model of a canoe and American Indian figure, who he names Paddle-to-the-Sea which he sets free on a bed of snow to have an adventure when the snow melts into the river. Indeed, he has many adventures as he travels from Northern Canada to the Atlantic Ocean and watercolor images on each page show Paddle-to-the-Sea traveling through a beaver pond, over waterfalls, and into a saw mill, where the little canoe is damaged and repaired by a lumberjack. After four years of journeying, he finally reaches the sea where he has a quick chance encounter with his creator (Holling, 1969).

The Mighty Hunter by Berta and Elmer Hader won an honor award in 1944 and features Little Brave Heart, a "brave little Indian boy," as he takes a day off of school to go hunting. Beginning with a small animal, each subsequently larger animal encourages him to wait for the prize of an even larger animal and when a large mother bear is angered to learn he is hunting for sport instead of need, she starts to chase him. He opts to head quickly to school (Hader, 1967). 
1945's winning book, Prayer for a Child, illustrated by Elizabeth Orton Jones and written by Rachel Field is the goodnight prayer of a little white girl. On just one page in particular, one sees a sea of children's faces intended presumably to represent the "other children, far and near" who appear in the young girl's prayer. From the coloring and clothing, one can deduce that the light brown boy and girl with dark hair in red headbands were probably intended to be representatives of American Indian people as the illustrator made an effort to include children of multiple backgrounds to accompany this text. A portion of this image appears on approximately one-third of the cover as well, surrounding an image of the white female child (Field, 1944).

The Thanksgiving Story illustrated by Helen Sewell and written by Alice Dagliesh was a 1955 honor book which tells the stereotypical story of Thanksgiving most Americans attending public school are taught: the story of the Mayflower voyage, settlement, hunger, and finally cooperation, friendship, and celebration with the American Indians. There are small stories within the text of the pilgrims' interactions with the American Indians but it is not until the last illustration that they are depicted at all. When they are finally illustrated, they are seated at the table with minimal clothing, beside the pilgrims, all smiling and eating (Dagliesh, 1988).

Houses from the Sea illustrated by Adrienne Adams and written by Alice E. Goudey is a 1960 honor book that tells the story of two children gathering shells on a beach. Illustrations depict their imaginings and in one such illustration, an American Indian man is shown handing shells to white man with text describing that Indians would use the shells as money or give them as gifts of peace to early white settlers. The 
American Indian is portrayed with dark skin, feathers in his hair, leather boots and a leather wrap (Goudey, 1959).

In 1963, The Sun is a Golden Earring illustrated by Bernarda Bryson and written by Natalia M. Belting received an honor award. Author and folklorist Natalia Belting tells the story of the sun by weaving excerpts from several cultures' tales to create one longer narrative. American Indian portions include legends from Navajo, Chippewa and Ute nations and some small pencil illustrations to accompany them. These illustrations include a man leaping from "mountain top to mountain top" (Ute) and another man floating atop a cloud while fashioning the sun from rock crystal (Navajo) (Belting, 1962).

The Angry Moon illustrated by Blair Lent and written by William Sleator received an honor award in 1971. An illustrator's note indicates that the style is based on Tlingit motifs, though they are not meant to be authentic. Accompanied by full watercolor and ink illustrations, the story is told of a young American Indian girl who insults the moon and is held prisoner by him until her friend reaches and rescues her. Both of the child characters are shown with brown skin, long dark hair, and wearing leather (the boy pants, the girl a knee-length dress). The boy is aided on his rescue mission by a child who appears to him and takes him to his grandmother for guidance. These child and grandmother figures appear to be loosely based on totem pole motifs themselves because although they have arms and legs like people, their heads resemble totem pole symbols (Sleator, 1970).

When Clay Sings written by Byrd Baylor and illustrated by Tom Bahti was awarded an honor in 1973. Illustrations inspired by pottery etchings fill the pages of this 
book about "ancient Indian pottery." The illustrator credits ancient potters from the Anasazi, Mogollon, Hohokam and Mimbres cultures (Baylor, 1972).

Arrow to the Sun, a Pueblo Indian tale written and illustrated by Gerald McDermott won the gold medal in 1975 to much controversy that continues to more contemporary times (McDermott, 1974). Selma G. Lanes wrote a scathing review in School Library Journal at the time stating that McDermott's illustrations "lumber graphically forward with about as much natural grace and motion as those mechanical rabbits that launch dog races" and calling the content "archaic" and "ludicrous" (Lanes, 1975). In more recent times, Debbie Reese has called into question the authenticity of parts of the tale, such as the "dance of life," which was created by McDermott according to his biographer (Reese, 2008). Reese expresses dismay at his depiction of their sacred kiva spaces as well as the "illegitimacy" of the protagonist, a concept which does not exist in the Puebloan family structure (Reese, 2006).

Peter Parnall was the illustrator and Byrd Baylor the author of two Caldecott honor books awarded in 1976 (The Desert is Theirs), and 1977 (Hawk, I'm Your Brother). In Desert, Baylor tells the story of the Papago Indians, or "desert people," and their interconnected relationship with the land. Parnall's simple illustrations are highlighted with color for select parts of the desert in each image. In Hawk, Baylor tells the story of a young boy who longs to fly. After nurturing an injured hawk to healing, he feels he does just that as the two are now intrinsically connected. Here, Parnall illustrated in just black and white. In each book, Parnall's simple illustrations gracefully aid Baylor's storytelling. Interestingly, although he does use color to emphasize portions of 
his artwork, in all three of his Caldecott titles, Parnall allows the American Indians' skin tones to match that of the paper: white.

1979 saw American Indians featured in both the winning book and an honor book. The Girl Who Loved Wild Horses written and illustrated by Paul Goble won the gold medal. This is the tale of an American Indian girl who loved horses so much she went to live among them eventually becoming one of them, forsaking her family and community. Unfortunately, this story appears to be another instance of a tribal legend with no source notes and no evidence of its existing as a Native story prior to Goble's publication (Reese, 2014a). He has gone on to tell more than 30 tales purportedly connected to American Indian legend. Perhaps he was responding to criticism for his appropriation of American Indians' stories when he began using a trickster character, Iktomi, to ridicule his critics within the introductory material of future picture books (Seale, 2005).

The Way to Start a Day illustrated by Peter Parnall and written by Byrd Baylor won a third honor for the duo. In this book, accompanied with Parnall's signature style, Baylor tells the story of multiple world people, including American Indians, singing a morning greeting. Here, Parnall chose predominantly yellow, turquoise and green to emphasize different parts of the landscape, with pink and turquoise as the primary colors for people's clothing (Baylor, 1978).

Where the Buffaloes Begin illustrated by Stephen Gammell and written by Olaf Baker won an honor award in 1982. Little Wolf, after hearing the legend of the origin of buffaloes, visits the site where they began and saves them from man. With soft black and white illustrations throughout, Gammell depicts a tale of plains Indians as they search for 
buffalo across prairies and hills to the lake, where they are said to be born. The American Indians depicted are shown with long dark hair, often on horseback, with fur and leather clothing (Baker, 1981).

In Grandfather's Journey, the 1994 medal winner written and illustrated by Allen Say about his grandfather, a single image of an American Indian man accompanies the text "He shook hands with black men and white men, yellow men and red men" (Say, 1993).

That same year, Raven, a Trickster Tale from the Northwest, written and illustrated by Gerald McDermott won an honor award. McDermott used the raven, which appears in a number of Pacific Northwest tribal legends, to create this tale of Raven's search for the sun (McDermott, 1993). Like Arrow to the Sun, Raven was not enthusiastically received by the American Indian community. One reviewer rated the book poorly due to "no acknowledgements and no introductions offered by any tribal agencies or personal acknowledgements from any Native peoples," yet did not acknowledge herself that it was intended to be an original tale influenced by tribal legends, not a legend itself (Martindale, 2004). Another took offense to this amalgamating of Pacific Northwest First Nations and felt "Universalizing and generalizing retellings such as this degrade sacred cultural teachings into mere tales" (Seale, 2005).

The American Indian made another appearance a 2009 honor book, A River of Words: The Story of William Carlos Williams, illustrated by Melissa Sweet and written by Jen Bryant. In this biography of William Carlos Williams, a collage includes the 
words "The Song of Hiawatha" beside a black and white image of two American Indians. Both have shoulder length dark hair, one is wearing feathers in his hair and the other is playing a flute (Bryant, 2008).

Two additional Caldecott titles feature white people dressed as American Indians. 1950 brought America's Ethan Allen, an honor book, illustrated by Lynd Ward and written by Stewart Holbrook. In this biography, Ethan Allen, a son of early colonists, is depicted as a pious and mighty builder. In a struggle for the right to some land, Allen's party dressed as "fake savages" to scare the conflicting party off and two separate illustrations feature white people dressed in a stereotypical feather and headband and American Indian clothing (Holbrook, 1949).

The following year, 1951, The Two Reds won a Caldecott honor award. Illustrated by Nicholas Mordvinoff and written by William Lipkind, this is the tale of a red-haired boy, "Red," and his red-haired cat who set off for adventures in their neighborhood. Red is soon in conflict with a band of white neighborhood boys who call themselves the Seventh Street Signal Senders. The Signal Senders - up to 15 in an image - are shown wearing full headdress or single feathers and with many wielding swords or bows and arrows. One is depicted with a cowboy hat (Lipkind, 1950).

American Indians have not appeared in a Caldecott title since 1994, over 20 years ago. Their appearances prior to that varied from being depicted as historical figures to appearing in tales purporting to be legends from several nations' oral traditions. As historical figures, the men are seen wearing feathers and leather and often engaged in trade or gifting white colonists with food or other materials. (The exception to that 
depiction is in They Were Strong and Good, in which the American Indian people are depicted as nuisances to the white settlers; this book is the only instance of a woman appearing as a historical figure.) When white men and boys are shown dressed as American Indians in two Caldecott books, America's Ethan Allen and The Two Reds, they are feared by other white people. Several of the stories are or purport to be American Indian legends. Just under half of the titles feature contemporary American Indians and in all of those they are seen communing with or coexisting supernaturally with nature, living in the desert, or working the land. Just three of the titles with an American Indian primary character are in a contemporary setting. There was a fairly steady, if not robust, presence into the early 80 s, when there was a 12-year gap followed by the current 22 year lapse. As described herein, only one American Indian, Velino Hererra, has illustrated a Caldecott title. In 2006, the American Indian Library Association established the American Indian Youth Literature Award "as a way to identify and honor the very best writing and illustrations by and about American Indians." Awards are given every two years to books that "present American Indians in the fullness of their humanity in the present and past contexts." Most recently, in 2016, the award for best picture book went to Little You illustrated by Julie Flett and written by Richard Van Camp, which was published by Orca Book Publishers in 2013 (American Indian Library Association, 2016).

\section{Asian and Asian American Representation}

Asian and Asian American people have appeared visually in 9\%, or 29, of the 332 Caldecott titles through 2016. These representations include Asian people from countries 
throughout the world such as America, China, Japan, Korea, Thailand, India, as well as many whose origin is indiscernible from images or text. As primary characters, they have appeared in 13 titles, of which three were gold medal winners (see Figure 7). Thirteen, or $1 \%$, of the 332 titles have been exclusively about Asians or Asian Americans. Of the 29, seven were illustrated by an Asian American and five were written by an Asian American. The first appearance of an Asian character was in $\mathrm{Mei} \mathrm{Li}$ in 1939, shortly after the inception of the award. The only time a gold medal has been awarded to a book in which the protagonist was Asian American was Grandfather's Journey, which was an historical tale about the author's Japanese grandfather's immigration experience decades earlier. The first Asian American to illustrate a Caldecott title was 12-year-old Plato Chan who illustrated his father's book, Good-Luck Horse, about a Chinese legend. Asian American illustrators and authors have created three Caldecott books in which no Asian or Asian American characters have appeared: Seven Blind Mice written and illustrated by Ed Young; The Adventures of Beekle: The Unimaginary Friend, written and illustrated by Dan Santat; and This One Summer, illustrated by Jillian Tamaki and written by Mariko Tamaki. A gold medal has never been awarded to a book with a contemporary Asian American primary character. However, contemporary Asian or Asian American characters have appeared as primary characters in five of the Caldecott titles. 


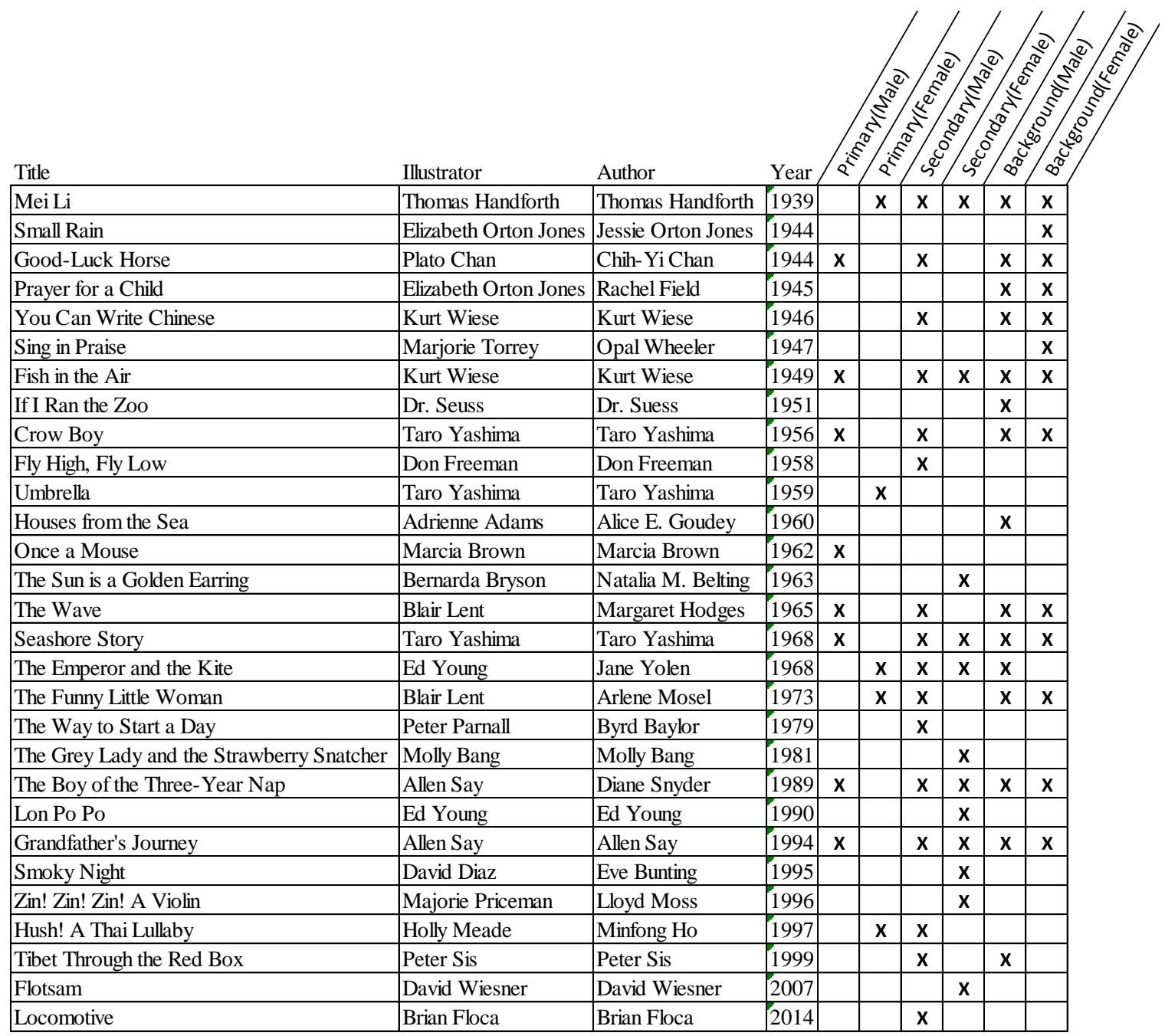

Figure 7. Caldecott titles in which Asian and Asian American people appear, through 2016. Data compiled from author's research.

In $1939 \mathrm{Mei} \mathrm{Li}$, which was written and illustrated by Thomas Handforth, won the gold medal. Mei Li, a little girl who lives in Northern China, must hurry home after visiting a nearby city for the New Year's fair. Set in contemporary 1930s, the text incorporates current activities with adherence to Chinese traditions and lore, such as returning from a new year celebration in time to greet the Kitchen God. There is a four color cover with black and white illustrations throughout (Handforth, 1938). 
Small Rain: Verses from the Bible, illustrated by Jessie Orton Jones and written by Elizabeth Orton Jones, received an honor award in 1944, features children from various ethnicities on several pages. There is an Asian girl on the cover and in three of the illustrations (Jones, 1943).

Good-Luck Horse was a 1944 honor title illustrated by Plato Chan and written by Chih-Yi Chan. This Chinese legend was illustrated in alternating orange and blue or black and white illustrations by the twelve-year-old son of the author (Chan, 1943; Peabody Bimonthly Booknotes, 1945).

Prayer for a Child, which won the medal in 1945, was also illustrated by Elizabeth Orton Jones and was written by Rachel Fields. Several Asian faces are depicted in the crowd with the other children on the page for the prayer for children "far and near" (Field, 1944).

In 1946, author and illustrator Kurt Wiese won an honor award for You Can Write Chinese, the story of an American boy named Peter attending a school in China. The book takes the reader on a journey with Peter as he learns to write several words in Chinese, many such as bamboo, ox and rice, significant to Chinese culture. Simple red and black or blue and black illustrations accompany the tale which was considered even decades later to be a "fine example of the way Chinese writing differs from our own" (Wiese, 1945; Orton Society, 1973).

Fish in the Air, which is set in China and was also written and illustrated by Kurt Wiese, won a 1949 silver medal. In this brightly illustrated tale of a boy named Fish, 
who loves all things having to do with fish, he is carried away by his giant fish kite in a big gust of wind (Weise, 1948).

Sing in Praise, a 1947 honor title illustrated by Marjorie Torrey and written by Opal Wheeler, includes a single page of multiple diverse faces in this 95-page book, one of which is an Asian girl carrying a baby on her back in a carrier (Wheeler, 1946).

If I Ran the Zoo, which was an honor book in 1951, was written and illustrated by Theodor Seuss Geisel. As protagonist Gerald McGrew travels the world seeking characters for his zoo, he goes for a hunt "in mountains of Zomba-ma-Tant, with helpers who all wear their eyes at a slant." The Asian characters, dressed in robes and exaggerated wooden clogs, are represented by three men balancing the "fine fluffy bird called the Bustard" in a cage on their heads. In addition, there is a reference to "eight Persian princes" who are depicted with exaggerated turbans and puffy pants carrying a basket of assorted creatures (Dr. Seuss, 1950).

An honor title for 1956, Crow Boy was written and illustrated by Taro Yashima and set in Japan. The first of three Caldecott titles to his credit, this is the story of a Japanese school boy who is taunted and ostracized by his classmates for being shy and unusual until the day they discover his extraordinary gift of mimicking crow calls. Full color illustrations help bring this story to life (Yashima, 1956).

Fly High, Fly Low, a 1958 honor book, was written and illustrated by Don Freeman. In the story set in San Francisco, Mr. Hi Lee, a Chinese man, feeds the pigeons regularly and follows them to their new home to continue caring for them (Freeman, 1957). 
In 1959, author/illustrator Taro Yashima won another honor award for illustrating Umbrella about a Japanese American girl who receives an umbrella on her third birthday and then has to wait patiently for the rain to come. This second Caldecott title from Yashima includes full color illustrations (Yashima, 1958). Decades later it is still appearing on recommended readings lists for Asian American children's literature for its universal experience of the Japanese American protagonist (Pang, et al. 1992).

Houses from the Sea, a 1960 honor book illustrated by Adrienne Adams and written by Alice E. Goudey, is the story of two children gathering shells on a beach. As they do so, they imagine limpets as Chinese hats and the accompanying illustration is of three Chinese men. Two are carrying one in a palanquin and they all wear the conical bamboo hats the limpets called to mind (Goudey, 1959).

Once a Mouse, the 1962 medal winner, was illustrated and retold by Marcia Brown. Woodblock prints in greens and reds tell this fable "from ancient India" featuring a male Indian hermit (Brown, 1961).

The Sun is a Golden Earring illustrated by Bernarda Bryson and written by Natalia M. Belting received an honor award in 1963. In this tale weaving several cultures' narratives to tell of the sun, there is an entry from India accompanying text which describes the shadows on the moon as an old woman spinning thread while her husband sits next to her smoking his long water pipe (Belting, 1962).

The Wave, a 1965 honor title illustrated by Blair Lent and written by Margaret Hodges, is an ancient Japanese tale of a grandfather who outwits nature and saves his village. This is the first of two Caldecott titles retold as children's stories that were 
originally collected by American journalist Lafcadio Hearn. Both were illustrated by Lent. This title is illustrated in shades of brown and black (Hodges, 1964).

In 1968 with Seashore Story, we see a third honor awarded to illustrator and author Taro Yashima. In this story, he returns to a Japan setting and tells the story of Japanese students who visit the seashore and wonder aloud at the meaning of a tale of a Japanese fisherman (Yashima, 1967).

The Emperor and the Kite, illustrated by Ed Young and written by Jane Yolen, received an honor award in 1968. Full color illustrations depict this tale of a young Chinese princess who, usually ignored by her father, saves him with her kite (Yolen, 1967).

The Funny Little Woman, the 1973 medal winner illustrated by Blair Lent and written by Arlene Mosel, is another book based on a tale collected by Lafcadio Hearn. In this tale, an old Japanese woman searches for a lost dumpling and outsmarts the tale's tricksters (Mosel, 1972).

The Way to Start a Day illustrated by Peter Parnall and written by Byrd Baylor was a 1979 honor title. In addition to diverse representation discussed in each of the other sections herein, there are depictions of Chinese, Japanese and Indian people with cultural iconography such as the Buddha in China and the Ganges in India (Baylor, 1978).

The 1981 medal winner, The Grey Lady and the Strawberry Snatcher, is a wordless picture book written and illustrated by Molly Bang. This tale features a blue man following a grey woman as he pursues her strawberries. There is a single image of 
an Asian woman, bejeweled and in colorful dress, holding a basket of snakes riding a skateboard (Bang, 1980).

The Boy of the Three Year Nap, a 1989 honor book retelling of a Japanese folktale, was illustrated by Allen Say and written by Diane Snyder. This first Caldecott book illustrated by Allen Say, with full color brush line illustrations, is the story of a Japanese mother who plots to change her son's lazy ways (Snyder, 1988).

Lon Po Po: A Red-Riding Hood Story from China, which was the 1990 gold winner, was the second Caldecott by Chinese-American Ed Young. This Chinese tale tells of three sisters who outsmart a wolf disguised as their grandmother (Young, 1989).

In 1994, Grandfather's Journey won the gold medal and was both written and illustrated by Allen Say. This story of Say's grandfather's life in America and Japan and love for both countries is illustrated with full color paintings. A Chinese man appears in the illustrations as well accompanied by the description "yellow" man (Say, 1993).

Smoky Night, the 1995 gold medal winner was illustrated by David Diaz and written by Eve Bunting. African American protagonist Daniel finds friendship with his Korean neighbor Mrs. Kim in the aftermath of the Los Angeles riots as the two bond over their found cats (Bunting, 1994).

Zin! Zin! Zin! A Violin, was a 1996 honor title illustrated by Marjorie Priceman and written by Lloyd Moss. The multicultural orchestra features an Asian female playing the flute (Moss, 1995).

Hush! A Thai Lullaby was a 1997 honor book illustrated by Holly Meade and written by Minfong Ho. The lullaby includes animals, such as a monkey, water buffalo 
and elephant which would be found in Thailand as well as illustrations of clothing and structural and natural environments authentic to the culture. Full-color cut-paper collage and ink illustrate this lullaby as a Thai mother asks the animals to let her baby sleep (Ho, 1996).

In Tibet Through the Red Box, a 1999 honor title, Peter Sis both illustrates and narrates the true story of his acquisition of his father's "red box," and the tales he discovered of his father's journeys in Tibet. Some of his father's encounters with the Tibetan people are included in the full color illustrations (Sis, 1998).

Flotsam, the 2007 gold winner, was illustrated by David Wiesner. In this wordless picture book about a camera washing up on shores around the world, readers see two Asian children as the camera makes its rounds (Wiesner, 2006).

Locomotive, the 2014 gold medal winner written and illustrated by Brian Floca, is about the first transcontinental railroad trip. Chinese people are shown carrying tools to work on the railroad at the beginning of the story as well as walking in a scene at the end of the book when the white family arrives at their Sacramento destination (Floca, 2013). In spite of their visual depiction, Floca was criticized for excluding the depth of their involvement in building the railroad from the text itself (Reese, 2014b).

With 29 of the books including a person of Asian descent, we see representation in almost $9 \%$ of the titles. Among these 29 titles featuring an Asian person in some capacity, eight were illustrated by an Asian American and six were written by an Asian American. However, as some recipients were recognized more than once, there are only four unique illustrators and four unique authors among these. There has been a steady 
appearance of Asian characters in the books over the years, with eight years being the greatest amount of time between books. However, Asian and Asian American people have been primarily depicted as foreign, historical or legendary figures. Although others have included contemporary settings in Asian countries, only four honor books have featured contemporary Asian American characters, a dearth of opportunities with which Asian American children might identify. There was no award winning book featuring an Asian as the primary character for the 21 years between 1968 and 1989 during which time the Asian population increased from $1 \%$ to $3 \%$ of the total population. The Asian/Pacific American Librarians Association (APALA) began issuing an award for picture books by and about Asians or Asian Americans in 2004 and issues the award every other year. There has never been any overlap in a book selected as a best or honor picture book by the APALA and Caldecott committees.

\section{Latino Representation}

Latinos have been visually represented in the Caldecott canon in a total of ten books, or $3 \%$. In six of these, or $2 \%$ of the Caldecott collection, the story was exclusively about Latinos. As primary characters, they have appeared in six, two of which were medal winners; as secondary characters in eight; and in seven as background characters (see Figure 8). Five of the six appearances as primary characters have been in a setting contemporary with the date of publication. There have been just two Latino illustrators of Caldecott books: David Diaz in 1995 and Yuyi Morales in 2015. Twenty years passed between Latino illustrators winning the Caldecott, which is the same amount of time that passed between appearances of a Latino person in a Caldecott. 
The first appearance of a Hispanic person as the primary character in a Caldecott book was 1939, the second year of the award. It wasn't until 1950 that the gold medal was awarded to a book featuring a person of Hispanic origin as the primary character. In fact, that gold medal went to Song of the Swallows, one of three Caldecott titles written and illustrated by Leo Politi, thus making him, an Italian-American, the primary representative of Latinos in the Caldecott collection to date.

\begin{tabular}{|c|c|c|c|c|c|c|c|c|c|}
\hline Title & Illustrator & Author & Year $/ a^{\circ}$ & & & & & & \\
\hline The Forest Pool & Laura Adams Armer & Laura Adams Armer & $1939 x$ & & $x$ & & $x$ & & $x$ \\
\hline Prayer for a Child & Elizabeth Orton Jones & Rachel Field & 1945 & & & & $x$ & & $x$ \\
\hline \begin{tabular}{|l} 
Pedro, the Angel of \\
Olvera Street \\
\end{tabular} & Leo Politi & Leo Politi & $1947 x$ & & $x$ & $x$ & $x$ & & $\underline{x}$ \\
\hline Sing in Praise & Marjorie Torrey & Opal Wheeler & 1947 & & & & $x$ & & \\
\hline \begin{tabular}{|l|} 
Juanita \\
\end{tabular} & Leo Politi & Leo Politi & 1949 & $x$ & $x$ & $x$ & $x$ & & $\underline{x}$ \\
\hline Song of the Swallows & Leo Politi & Leo Politi & \begin{tabular}{|l|l|}
1950 & $x$ \\
\end{tabular} & & $\mathrm{x}$ & & $x$ & & $x$ \\
\hline Nine Days to Christmas & Marie Hall Ets & Aurora Labastida & 1960 & $x$ & $x$ & $x$ & $\mathrm{X}$ & & $x$ \\
\hline The Way to Start a Day & Peter Parnall & Byrd Baylor & 1979 & & $x$ & $x$ & & & \\
\hline Smoky Night & David Diaz & Eve Bunting & 1995 & & $x$ & $x$ & & & \\
\hline Viva Frida & Yuyi Morales & Yuyi Morales & 2015 & $x$ & $x$ & & & & \\
\hline
\end{tabular}

Figure 8. Caldecott books in which Latinos were represented, 1939-2016. Data compiled from author's research.

The first appearance of a Latino person in a Caldecott was in The Forest Pool written and illustrated by Laura Adams Armer which won an honor in 1939. This story of two Mexican boys trying to capture an iguana is illustrated with colorful paintings of the two boys as they explore the forest in near their Mexican homes. Their light brown 
skin, black hair and simple clothing appear against the backdrop of luscious greens, reds and oranges.

Prayer for a Child illustrated by Elizabeth Orton Jones and written by Rachel Field won an honor in 1945 and, like the American Indian representation described earlier, features what is likely Latino children on the page depicting "other children, far and near.” In a sea of faces of many colors, one sees a brown child with straight dark hair wearing what is most likely a sombrero. It seems that it was the author's intent to portray as many cultures "far and near" as she could in this image filled with colorful faces. Portions of the image are repeated on the cover as well (Field, 1944).

Pedro, the Angel of Olvera Street, which was written and illustrated by Leo Politi, won an honor award in 1947. This is the first instance of a Latino child portrayed as the primary character. Primarily illustrated in full color, the book portrays Pedro, a Mexican American boy, living on a busy street in Los Angeles. Dozens of characters are depicted in a variety of imagery including bustling street scenes, men working such trades as blacksmith and pot maker, and community festivities. Because of his beautiful singing voice, Pedro is chosen to lead the Posada, a processional play of the story of Mary and Joseph. Dozens of Mexican Americans are shown in each illustration with the exception of one page of music where four angels are represented as white children. In the small nativity set, Joseph is wearing a sombrero (Politi, 1946).

Sing in Praise: A Collection of the Best Loved Hymns, illustrated by Marjorie Torrey and written by Opal Wheeler won an honor award in 1947. Like Prayer for a Child, it includes just one page with diverse people. In this case, it is an image on the 
verso page of Jesus surrounded by fifteen children, four of whom are children of color one of which is wearing a poncho and sombrero. The other 94 pages feature Christian hymns, their history, and images of white people (Wheeler, 1946).

In 1949, Leo Politi won another honor award with Juanita. In Juanita, Politi returns once again to Olvera Street in downtown Los Angeles, this time with a female protagonist. With full color and black and white illustrations, he once again highlights festivities of the Mexican American culture. The Blessing of the Animals, Easter and Juanita's birthday are the focus of this tale featuring only Mexican Americans (Politi, 1948).

Song of the Swallows, written and illustrated by Leo Politi, won a gold medal in 1950, and was Politi's last Caldecott title. In Song of the Swallows, Politi leaves the Los Angeles setting and takes his readers to the Mission of San Juan Capistrano and the relationship between young Juan and the mission's gardener, Julian. Together, they enjoy the swallows' song, their birth and growth, eventual migration and-much to Juan's delight — their return. Full color illustrations of the coastline, farm and mission grounds help to illustrate this tale (Politi, 1949).

Another book featuring a Mexican celebration, Nine Days to Christmas, illustrated by Marie Hall Ets and written by Aurora Labastida (Lembke, 1962), won a gold medal in 1960. Hall Ets' illustrations take viewers on a journey with young Ceci as she and her family plan their Christmas posada. Illustrations depicting excited piñatas coming to life for Ceci as they try to convince her to take them home for the party and 
colorful depictions of life in a Mexican town add vibrancy to this tale of a Mexican experience (Labastida, 1959). This is the only winning title by a Latino author.

The Way to Start a Day, illustrated by Peter Parnall and written by Byrd Baylor, won an honor award in 1979. Baylor tells the story of multiple world cultures through the song of a morning greeting in which people "leap and sway to Aztec flutes in Mexico," and "chant at dawn in the sun temples of Peru" which are the two images representing Latinos. With a simple color palette, Parnall weaves images of the cultures' people into its landscapes (Baylor, 1978).

Smoky Night, illustrated by David Diaz and authored by Eve Bunting, received the gold medal in 1995. This is the story of one family's experience following the riots in Los Angeles that occurred after the verdict in the Rodney King trial in 1993. The controversy surrounding this particular book is discussed more fully herein under the African/African American Representation section. However, the Latino representation in Smoky Night is in the form of the Ramirez family, a mother and father with their two children who are escaping their burning building along with the African American protagonist Daniel and his mother. The illustrator used a variety of collage materials including soles of shoes, cereal and dry cleaning supplies to add depth to his colorful acrylic paintings. The people in Smoky Night are all depicted with similar features though the Latino family and Korean woman appear to have lighter skin (Bunting, 1994).

Viva Frida, written and illustrated by Yuyi Morales, won an honor award in 2015. Morales uses the mediums stop-motion puppets made from steel, polymer clay, and wood, acrylic paints, photography, and digital software to create the images of Frida 
Kahlo in this vibrant biography. Viva Frida was also the Pura Belpré medal winner for illustration in 2015 (Morales, 2014).

Among the Caldecott books, only three authors and two illustrators have been of Hispanic origin. The first Latino author was in 1960 with Aurora Labastida's Nine Days to Christmas and the next not for 55 years, when Yuyi Morales won an honor for Viva Frida. The third, Last Stop on Market Street, was authored by Matt de la Peña and won an honor in 2016 (de la Peña, 2015).

David Diaz won the medal in 1995 and twenty years passed before Yuyi Morales won an honor for Viva Frida. Three of the ten Caldecott books featuring a Latino character were written and illustrated by Leo Politi, an Italian American.

In fact, there are only 10 instances of the 332 Caldecott titles in which a person who is demonstrably of Hispanic origin appears. Of these, six remain in print: Prayer for a Child, The Way to Start a Day, Smoky Night, Viva Frida, and all three books by Leo Politi. This translates to just 3\%, in spite of the fact that, other than white, Hispanic people make up the majority of the population. Fully 20 years passed between appearances of a Latino person in Caldecott books while our nation's population went from $6.4 \%$ Hispanic in 1980 to $17.4 \%$ in 2014. (Data was not collected for the Hispanic population prior to 1980 and 2014 is the most recent year for which we have data.) (Gibson \& Jung, 2005). During this period of significant growth in the Hispanic population, one out of 143 Caldecott books featured a Latino person in any capacity: Smoky Night. The Latino representation in Smoky Night was of a family living in the same building as the African American protagonist. 


\section{Indeterminate Representation}

The following is a list of 20 books designated "indeterminate" because the content was lacking in cultural specificity or text to help enable the determination of a character(s)'s race. In some, such as Nana and the City, the first instinct was to catalog the dark-skinned man dancing on the street to music from a portable stereo as African American (Castillo, 2014). Upon further reflection, it was determined by the researcher that this man could be a mirror to any number of dozens of racial groups including Latino, Filipino, Tongan, African American, Cambodian, and numerous others. For this reason, this book is included in this Indeterminate category. Likewise, in others, such as Knuffle Bunny, Too and More More More Said the Baby, the ambiguous identity of some of the characters offers an opportunity for multiple cultures to meaningfully participate in the narrative (Willems, 2007; Williams, 1990).

In Prayer for a Child, the 1945 medal winner illustrated by Elizabeth Orton Jones and written by Rachel Field, there is the one multicultural image previously mentioned in each of the categories. Many cultures were able to be determined based on either stereotypical or culturally-specific images of clothing, headwear or hair style and/or

texture. In addition to the identifiable images in this sea of many faces, there are many whose heritage is indiscernible (Field, 1944).

In Sing Mother Goose, an honor book from 1946 illustrated by Marjorie Torrey and written by Opal Wheeler, there is a single black face in the 104-page book. He is dressed in what may be Indian or North African clothing holding the dress train of a white girl. This image accompanies the lyrics to "A Little Nut Tree," which is about the 
"queen of Spain's daughter" visiting. In addition, there is a white boy and a monkey in the image, both dressed in European clothing (Wheeler, 1945).

One Wide River to Cross, a 1967 honor book illustrated by Ed Emberley and written by Barbara Emberley purports to be a "rollicking picture book adaptation of the traditional African-American spiritual." From the endnotes, it appears to be a Noah's ark story, yet the animals enter the ark not just two by two but four by four, five by five, and so on up to ten. Mythical animals such as unicorns and griffins are included as well as roller skating. There is no way to discern what race the human characters are although it is an African American spiritual (Emberley, 1966).

A 1972 honor award, If All the Seas Were One Sea, written and illustrated by Janina Domanska, explores how the world would look like if everything were one, if all men were one man. A colorful composite of a number of geometric shapes illustrates this tale which includes an image of a multi-hued man made up of green, red, blue and black (Domanska, 1971).

In 1981, The Grey Lady and the Strawberry Snatcher, written and illustrated by Molly Bang, received an honor award. In this tale, a grey lady is followed by a blue creature apparently seeking her strawberries. Having escaped the blue strawberry snatcher, she goes home to her family of racial ambiguity (although with arguably brown skin instead of grey) to share her strawberries (Bang, 1980).

A Chair for My Mother, a 1983 honor book written and illustrated by Vera Williams features a family that is all white. There are many brown faces in a street scene but their race is difficult to determine lacking description in the text (Williams, 1982). 
More More More Said the Baby: Three Love Stories, a 1991 honor book written and illustrated by Vera Williams features an African American baby in one of the three stories. In the final story, a duo is featured that could provide a mirror for any number of races including Asian American, American Indian, Latino and others (Williams, 1990).

In the Small, Small Pond, a 1994 honor winner illustrated and written by Denise Fleming, the reader sees one child who is depicted on both the cover and the first pages. This light brown child could be any gender, or one of many races. Although the story focuses on a frog's experience of the seasons in its pond, this presents an opportunity for many children to find themselves in this experience of the everyday. Colored pulp poured into hand cut stencils illustrate this vibrant tale (Fleming, 1993).

In 1996's medal winner, Officer Buckle and Gloria, written and illustrated by Peggy Rathmann, the reader hears the tale of a police officer and his successful safety seminars with his dog companion. A number of student faces appear in each audience. Some varying shades of brown with different textures of hair may be intended to represent children of various races. In addition, there is a brown-skinned teacher whose race is not easily determined. Full color illustrations throughout embellish this amusing tale (Rathmann, 1995).

Sector 7 is a 2000 honor book written and illustrated by David Wiesner. In this wordless picture book, a boy embarks on a journey from a cloud at the top of the Empire State Building. A few brown faces of indiscernible race appear in the illustrations, one of which works in a lab and one that is on the street (Wiesner, 1999). 
In Ugly Duckling, a 2000 honor winning adaptation of the Hans Christian Andersen tale, author and illustrator Jerry Pinkney portrays the story with full color watercolor paintings. In one scene a dark-skinned man is seen rescuing the swan for his children, who are depicted in the background. Their race is indiscernible in the illustration or text (Pinkney, 1999).

The Hello, Goodbye Window was the 2006 gold medal winner illustrated by Chris Raschka and written by Norton Juster. In this story of a little girl's time spent with her grandparents, the reader sees the girl, her parents and grandparents. Both the mother and grandmother (with the exception of one image where the grandmother is clearly white with the text "Nanna is English") are pictured with dark skin and the father and grandfather with light skin. The girl's skin is a color in between. It is hard to tell what Raschka's intentions were, if this is a multiracial or biracial family and, if so, what race(s) they are intended to represent (Juster, 2005).

Knuffle Bunny, Too: A Case of Mistaken Identity, was a 2008 honor medal written and illustrated by Mo Willems. In this follow-up story to Knuffle Bunny, the protagonist's stuffed bunny is mixed up with that of a classmate's. The classmate and her father have much darker hair and skin but there are no cultural or other references to aid in the discerning of their race. There are other classmates and pedestrians depicted with dark skin but their race is indiscernible as well (Willems, 2007).

The House in the Night, the 2009 medal winner illustrated by Beth Krommes and written by Susan Marie Swanson, names the many things one can't see in the night. It includes a young girl whose race is unable to be determined. Illustrated in black, white 
and yellow with scratchboard and watercolor, there are no discernible characteristics to help define her race (Swanson, 2008).

A 2009 honor book, A River of Words: The Story of William Carlos Williams, illustrated by Melissa Sweet and illustrated by Jen Bryant includes two small background images of dark-skinned males with no evidence of their racial identity in the words or image (Bryant, 2008).

In All the World, which won an honor award in 2010 and was illustrated by Marla Frazee and written by Liz Garton Scanlon, a number of families appear throughout this book which highlights the life of a community. Some of the people in the community have darker skin but there is no identifying text or clear imagery (Scanlon, 2009).

In Blackout, a 2012 honor book written and illustrated by John Rocco, a street scene features a number of people outside enjoying the dark. People with darker skin are shown but nothing to identify their race is present (Rocco, 2011).

Nana and the City is a 2015 honor title written and illustrated by Lauren Castillo. In this tale about a little boy visiting his grandmother in the big city, a number of diverse characters appear in several of the illustrations but other than darker skin, nothing to clearly identify their race or ethnicity is evident (Castillo, 2014).

The Adventures of Beekle, an Unimaginary Friend, was the 2015 medal winner written and illustrated by Dan Santat, about an imaginary friend in search of his human. The readers see a number of darker-skinned people in a variety of background images. Other than dark skin, there is nothing to indicate their race (Santat, 2014). 
In a 2016 honor title, Last Stop on Market Street, illustrated by Christian Robinson and written by Matt de la Peña, a number of characters with varying shades of skin appear in the background. Lacking cultural specificity, there is no way to determine their race (de la Peña, 2015).

\section{Limitations and Further Research}

While this review of the Caldecott winning collection did focus on a specific and important subset of books, it was not a thorough examination of every picture book published and thus not a comprehensive look at how diversity is depicted in all picture books. And although these books remain fairly easy to access throughout the ages, and many are likely to be used in educational settings, they are not necessarily the popular books children are asking their caregivers to read repetitively. Even though they are available, if few children are being exposed to them their negative impact is obviously reduced. Unfortunately, in the case of several of the books, the harmful stereotyping is still present.

Additionally, there are many ways to interpret literature and there is no real way to know how a particular book impacts an individual child's reading. Noting what they will see and hear during a reading is just the beginning of trying to understand the influences early literature will have on their lives.

Recording diverse representations in the books as a whole versus per illustration (as was done in some studies noted in the literature review) skewed the data differently than counting each face in each book. For example, in a winning year where a single African American face is depicted in one of five books, it was recorded that there was an 
African American character in $20 \%$ of that year's winners. However, it may be that among these winners, there are one hundred images of white faces and one image of a Black face, in which case the diversity a reader is visually exposed to was just $1 \%$.

Of course, the Caldecott collection has been developed over 79 years and it is unlikely that the entire collection could match today's diversity. While diverse representation within the picture book has not kept pace with the population, the onus was not on each year's committee to anticipate the structure of the future population nor to base their decisions on any such factors.

Not all of the data collected for this research appear in this narrative. The data can be examined from a number of angles and the information presented here represents just a few "snapshots." For example, data could be extracted that would illuminate any number of time periods, depth of representation, or illustrator and author trends.

In addition, the way the United States collects census data has fluctuated constantly. Even with attempts at improvement, as recently as 2010 it did not allow for accurate counting of different ethnicities, let alone multi- or bi-racial people. Accurate collection is also dependent on education level and interest of the census takers, their ability to spell the names of the people they are interviewing, whether neighbors or children are interviewed, and so forth. However, these data from a system wrought with error are likely the best we have for this purpose.

More research into what was happening socially in the country during the time leading up to each award year may shed some light on the social construct within which each of the committees were living. 


\section{Summary and Conclusion}

It is hoped that this research will contribute to a new perspective on children's literature and the body of Caldecott Medal winners in particular. An informed discussion about how racial diversity has been represented in this body of work as compared to the diversity in our society will enable professionals to structure their conversations about the need for change with statistical accuracy. This information will be useful to authors, publishers, librarians, booksellers, educators, and all of those who work to help positively impact the lives of our children. The data will help propel the conversation around the vital work of ensuring access to excellent, diverse literature for our youth.

With the exception of the quality of African American content, there has been no more diversity in the Caldecott winners since the addition of awards to encourage diverse authors and content. Since the American Indian Library Association initiated an award in 2006, there has not been a single book by or about an American Indian. Since the Asian Pacific American Library Association issued the first in award in 2003, there have only been two books featuring an Asian character in any capacity (Flotsam and Locomotive), neither by or about Asian characters but merely including them as a secondary or background character. Following the establishment of the Pura Belpré in 1996, there have been only two Latino illustrators awarded an honor (Yuyi Morales and Matt de la Peña) and only one, Viva Frida, has included a Latino character. Since its inception in 1970, the Coretta Scott King Award has been awarded to many African American illustrators and authors. The overlap Coretta Scott King and Caldecott awards have both honored twelve of the same titles. The Caldecott committees have acknowledged several 
additional titles featuring African Americans in different capacities during these 46 years since it started. Because the criteria are different (i.e., the author or illustrator do not have to be African American), the Caldecott committees can choose from a larger pool. In addition, this research has included books in which Africans or African Americans are featured in any capacity, regardless of role or quality of depiction.

Although not the highest in diverse populations, Black people have been visually represented in the Caldecott books more than any other racial group, in 19\%, or 62 of the 332 books. The majority of these portrayals feature Blacks as historic, take place in another country, or are African or African American folktales. Six percent (21 titles) included images of American Indians in some capacity. Their appearances vary from being depicted as historical figures to appearing in tales purporting to be legends from several nations' oral traditions. Asian and Asian American people have appeared visually in $9 \%$, or 29 , of the 332 books. These representations predominantly include Asian people from countries other than the United States. While the second largest proportion of the United States population, Latinos have only been visually represented in the Caldecott canon in a total of ten, or 3\%, of the books.

While it does not cover the diversity of the United States from the inception of the Caldecott through today, the image below is a snapshot of total diversity in the books and the diversity among primary characters in the 332 books compared to the total diversity of the United States today, which is significant as the majority of these award winners are still available on library bookshelves, and in classrooms or stores (see Figure 9). 


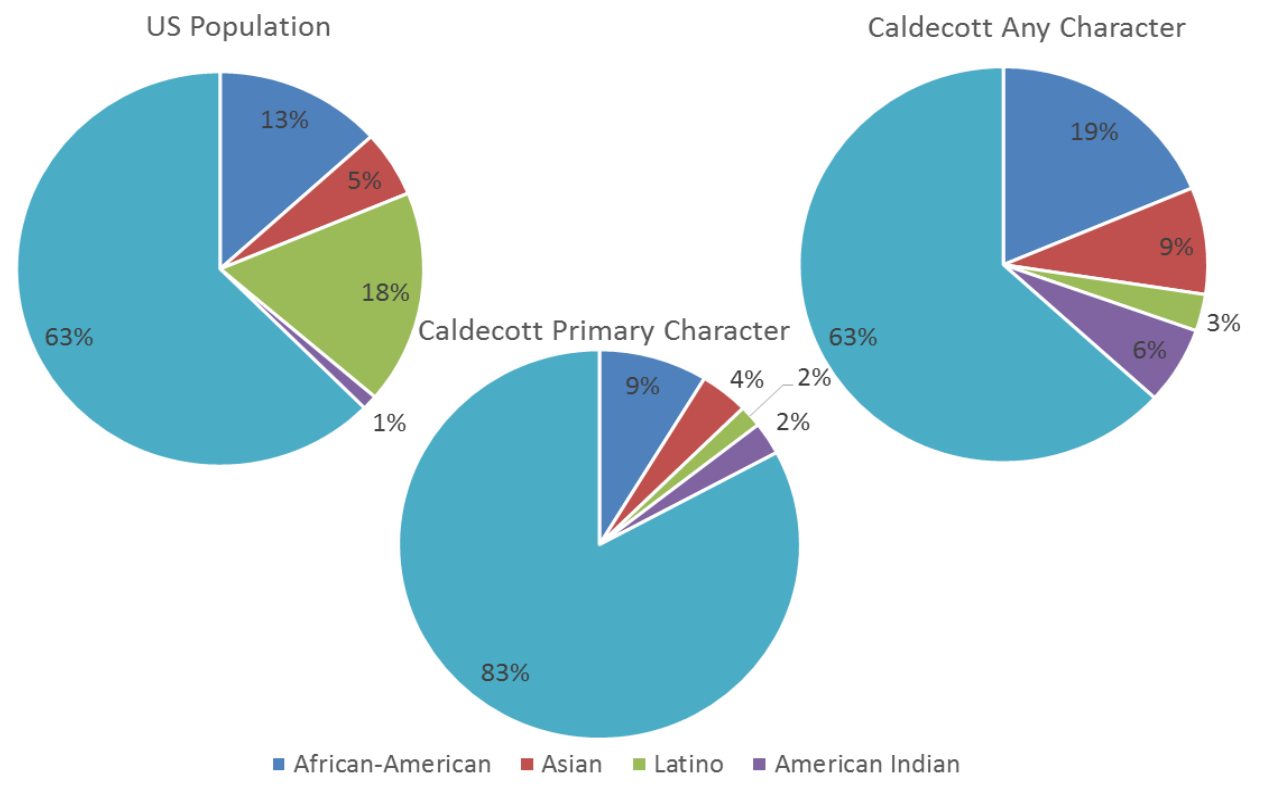

Figure 9. Multicultural representation vs. US population. Data compiled from author's research and United States Census Bureau, 2015.

The $43 \%$, or 142 of 332 books, in which people of color, American Indians and people whose visual depiction allows for access by multiple races, seems sufficient — or even high - at first glance. Unfortunately, the diverse representation takes on many forms and this number does not reflect the quality of the representation. The vast majority of books featuring American Indians or people of color depict them with stereotyped roles or appearances, in historical settings, in foreign settings, in fantastic settings, legendary settings, or folk or fairytale settings.

Since most of the books featuring diverse people present them as historical or fantastical, are folk or fairytales, or take places in countries other than the United States, these genres do not provide a mirror of a child's own world but serve only as a window 
even when the protagonist is of the same race. In fact, of these 142 books including diverse representation, only 61 (or 18\%) feature the person(s) of color, American Indian or indeterminate character as the primary character. Of these, a mere $29(>1 \%)$ are in a non-fantasy setting contemporary with the date of publication and just 21 of those are set in the United States. This means that less than $1 \%$ of the Caldecott winning and honor books have included a primary character in a setting in which a child of color or American Indian from the era could actively identify. The diversity among authors and illustrators is even less than the meager primary character representation (see Figure 10).

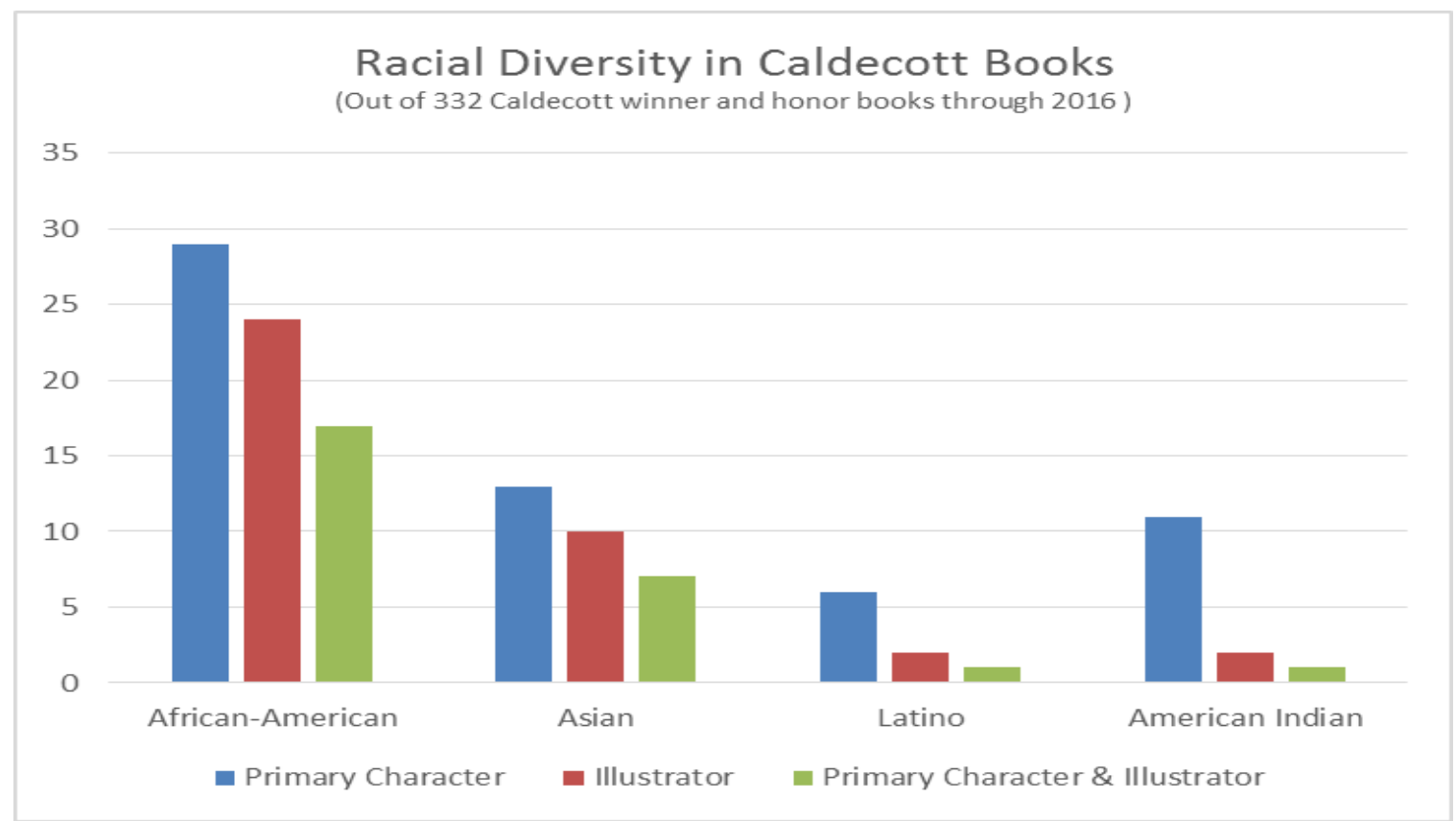

Figure 10. Racial diversity in Caldecott books. Data compiled from author's research.

It is important to remember that the award committees are composed of people who are existing in and a product of their time. Likewise, the illustrators, authors and consumers are products of their time. Sensibilities change over time, as has been 
acknowledged with the books that have been revised. Interestingly, publishers recognize the staying power of these award winners and attempt to update them by revising or eliminating the offensive material. In the case of They Were Strong and Good and Abraham Lincoln, this was not successful. In spite of the assumed staying power of the award winners, it may be time to let some of them disappear into the annals of history if we want literature for our youth that reflects the evolution of thought and new understanding of a child's development that each year brings. Giving a child a mirror in which to view smart, strong, successful people who look like them in lieu of stereotyped, subservient or foreign people who look like them is critical to their self-identity and, ultimately, to their success. Giving other children the images available in the canon of Caldecott books as windows into other races' identities does not serve the best interest of any child as it perpetuates the stereotypes and keeps the vision of "other" as an unknown, foreign presence or worse, inferior. 


\section{References}

Aardema, V. (1975). Why mosquitos buzz in people's ears. (L. \& D. Dillon, Illus.) New York, NY: The Dial Press.

American Indian Library Association. (n.d.). American Indian Youth Literature Award. Retrieved from http://ailanet.org/activities/american-indian-youth-literatureaward/

American Library Association, Association for Library Service to Children. (n.d.). The Randolph Caldecott Medal. Retrieved from http://www.ala.org/alsc/awardsgrants/bookmedia/caldecottmedal/aboutcaldecott/a boutcaldecott

American Library Association, Association for Library Service to Children. (2016). Caldecott Medal \& Honor Books, 1938-Present. Retrieved from http://www.ala.org/alsc/awardsgrants/bookmedia/caldecottmedal/caldecotthonors/ caldecottmedal

American Library Association. (2016). The Coretta Scott King Book Awards. Retrieved from http://www.ala.org/emiert/cskbookawards

American Library Association. (n.d.). Pura Belpré Award. Retrieved from http://www.ala.org/awardsgrants/pura-belpr\%C3\%A9-award

Andrews, T. (2015). Trombone Shorty. New York, NY: Abrams Books for Young Readers.

Aronson, M. (2001). Slippery slopes and proliferating prizes. Horn Book Magazine, 77(3), 272-278.

Asian Pacific American Library Association (n.d.) Literature Awards. Retrieved from http://www.apalaweb.org/awards/literature-awards/

Baker, A. (1963) Books about negro life for children. New York, NY: The New York Public Library.

Baker, O. (1981). Where the buffaloes begin. (S. Gammel, Illus.). New York, NY: Frederick Warne \& Co.

Bang, M. (1980). The grey lady and the strawberry snatcher. New York, NY: Simon \& Schuster Children's Publishing.

Bang, M. (1983). Ten, nine, eight. New York, NY: Greenwillow Books. 
Barthelmess, T. (2015). Caldecott and Newbery 2015. Retrieved from http://www.hbook.com/2015/07/choosing-books/horn-book-magazine/caldecottand-newbery-2015

Baylor, B. (1972). When clay sings. (T. Bahti, Illus.). New York, NY: Charles Scribner's Sons.

Baylor, B. (1975). The desert is theirs. (P. Parnall, Illus.) New York, NY: Charles Scribner's Sons.

Baylor, B. (1976). Hawk, I'm your brother. (P. Parnall, Illus.) New York, NY: Charles Scriber's Sons.

Baylor, B. (1978). The way to start a day. (P. Parnall, Illus.). New York, NY: Charles Scriber's Sons.

Belting, N. M. (1962). The sun is a golden earring. (B. Bryson, Illus.). New York, NY: Holt, Rinehart and Winston.

Benes, R. C. (2004). Native American picture books of change. Santa Fe, NM: Museum of New Mexico Press.

Bishop, R.S. (2001). Choosing books. Horn Book Magazine. Retrieved from http://www.hbook.com/2001/09/choosing-books/horn-book-magazine/letterseditor-septemberoctober-2001/

Boulais, N. A. (2002). Leadership in children's literature: Qualitative analysis from a study based on the Kouzes and Posner leadership framework. Journal of Leadership \& Organizational Studies, 8(4), 54-63. Retrieved from http://search.proquest.com.libaccess.sjlibrary.org/docview/203135398?accountid= 10361

Boyd, J. (1958). Passports to the promised land. Elementary English, 35(7), 441-449.

Brown, M. (1949). Henry-Fisherman: A story of the Virgin Islands. New York, NY: Charles Scribner's Sons.

Brown, M. (1950). Dick Whittington and his cat. New York, NY: Charlies Scribner's Sons.

Brown, M. (1961). Once a mouse... New York, NY: Charles Scribner's Sons.

Brown, M. (1982). Shadow. New York, NY: Charles Scribner’s Sons. 
Bryant, J. (2008). A river of words. (M. Sweet, Illus.) Grand Rapids, MI: Eerdmans Books for Young Readers.

Bunting, E. (1994). Smoky night. (D. Diaz, Illus.). San Diego, CA: Harcourt, Brace.

Carrick, L. C. (2009). Dave the potter. NewYork, NY: Little Brown and Company.

Castillo, L. (2014). Nana in the city. New York, NY: Clarion Books.

Chan, C. (1943). Good-luck horse. (P. Chan, Illus.) New York, NY: McGraw-Hill Book Company

Chodos-Irvine, M. (2003). Ella Sarah gets dressed. San Diego, CA: Harcourt.

Clark, A. N. (1969). In my mother's house. (V. Herrara, Illus.). New York, NY: The Viking Press (Original work published 1941).

Clark, B. L. (1992). American children's literature: Background and bibliography. American Studies International, 30(1), 4-40.

Cooperative Children's Book Center. (2015, February 24). Children's books by and about people of color published in the United States. Retrieved from https://ccbc.education.wisc.edu/books/pcstats.asp

Crisp, T., \& Hiller, B. (2011). Is this a boy or a girl?: Rethinking sex-role representation in Caldecott Medal-winning picturebooks, 1938-2011. Children's Literature in Education 42(3), 196-212.

Dagliesh, A. (1988). The Thanksgiving. Story. (H. Sewell, Illus.). New York, NY: Charles Scribner's Sons. (Original work published 1954).

Daugherty, J. (1964). Andy and the lion. New York, NY: The Viking Press. (Original work published 1938)

d'Aulaire, I. P. \& d'Aulaire, E. P. (1957). Abraham Lincoln. Garden City, NY: Doubleday \& Company, Inc. (Original work published 1939)

d'Aulaire, I. P. \& d'Aulaire, E.P. (2015). Abraham Lincoln. Santa Barbara, CA: Beautiful Feet Books.

Dayrell, E. (1968). Why the sun and the moon live in the sky. (B. Lent, Illus.) Boston, MA: Houghton Mifflin.

de la Peña, M. (2015). Last stop on Market street. New York, NY: G.P. Putnam’s Sons. 
Domanska, J. (1971). If all the seas were one sea. New York, NY: Aladdin Children's Books.

Dr. Seuss. (1950). If I ran the zoo. New York, NY: Random House.

Emberley, B. (1972). Drummer Hoff. (E. Emberley, Illus.) Englewood Cliffs, N. J.: Prentice-Hall. (Original work published in 1967)

Feelings, M. (1971). Moja Means One: Swahili Counting Book. (T. Feelings, Illus.) New York, NY: The Dial Press.

Feelings, M. (1974). Jambo means hello. (T. Feelings, Illus.) New York, NY: The Dial Press.

Field, R. (1944). Prayer for a child. (E. Orton Jones, Illus.) New York, NY: MacMillan Publishers.

Fleming, D. (1993). In the small, small pond. New York, NY: Henry Holt and Company.

Floca, B. (2013). Locomotive. New York, NY: Simon \& Schuster Children's Publishing.

Freeman, D. (1957). Fly high, fly low. New York, NY: The Viking Press

Gibson, C., \& Jung, I. (2005). Historical census statistics on population totals by race, 1790 to 1990, and by Hispanic origin, 1970 to 1990, for large cities and other urban places in the United States. Retrieved from https://www.census.gov/population/www/documentation/twps0076/twps0076.pdf

Giovanni, N. (2005). Rosa. (B. Collier, Illus.) New York, NY: Henry Holt \& Company.

Glass, N. (2013). Getting 'the call'. Children \& Libraries: The Journal of The Association for Library Service to Children, 11(1), 29-34.

Goble, P. (1978). The girl who loved wild horses. Scarsdale, NY: Bradbury Press.

Goudey, A. E. (1959). Houses from the sea. (A. Adams, Illus.). New York, NY: Charles Scribner's Sons.

Grifalconi, A. (1986). The village of round and square houses. Boston, MA: Little, Brown \& Company.

Hader, B. \& Hader, E. (1967). The Mighty Hunter. New York, NY: MacMillan Publishers. (Original work published 1943). 
Haley, Gail. (1971). A story a story. New York, NY: Atheneum. (Original work published 1970).

Hamilton, V. (2001). Choosing books. Horn Book Magazine. Retrieved from http://www.hbook.com/2001/09/choosing-books/horn-book-magazine/letterseditor-septemberoctober-2001/

Handforth, T. (1990). Mei Li. New York, NY: Bantam Doubleday Dell Publishing Group. (Original work published 1938)

Hill, L. C. (2010). Dave the potter. (B. Collier, Illus.) New York, NY: Little, Brown \& Company.

Ho, M. (1996). Hush! A Thai lullaby. (H. Meade, Illus.) New York, NY: Orchard Books.

Hodges, M. (1964). The wave. (B. Lent, Illus.) Boston, MA: Houghton Mifflin.

Holbrook, S. (1949). America's Ethan Allen (L. Ward, Illus.). Boston, MA: Houghton Mifflin.

Holling, H. C. (1969). Paddle-to-the-Sea. Boston, MA: Houghton Mifflin. (Original work published 1941).

Horning, K. T. (2010). Can children's books save the world? Advocates for diversity in children's books and libraries. Children and Libraries, Winter, 8-16.

Howard, E. F. (1983). Shadows and Marcia Brown's shadow. Horn Book Magazine. Retrieved from http://www.hbook.com/1983/10/choosing-books/horn-bookmagazine/shadows-and-marcia-browns-shadow/

Isaacs, A. (1994). Swamp angel. (P. O. Zelinsky, Illus.) New York, NY: Dutton Children's Books.

Isadora, R. (1979). Ben's trumpet. New York, NY: Greenwillow Books.

Jones, J. O. (1943). Small rain: Verses from the Bible. (E. Orton Jones, Illus.) New York, NY: The Viking Press.

Juster, N. (2005). The hello, goodbye window. (C. Raschka, Illus.) New York, NY: Hyperion Books for Children.

Keats, E. J. (1962). The snowy day. New York, NY: The Viking Press. 
Keats, E. J. (1969). Goggles! New York, NY: MacMillan.

Killeen, E. B. (2012). A rewarding experience. Teacher Librarian, 40(2), 59-60.

Kirch, C. (2014). After outcry, ReedPOP promises to diversify author panel. Retrieved from http://www.publishersweekly.com/pw/by-topic/childrens/childrens-industrynews/article/61836-reedpop-promises-to-add-to-bookcon-panel-aftercriticisms.html

Klein, R. (2015). In 10 years, America's classrooms are going to be much more diverse than they are now. Retrieved from http://www.huffingtonpost.com/2015/05/07/classroom-demographics2025_n_7175760.html

Koss, M. D. (2015). Diversity in contemporary picturebooks: A content analysis. Journal of Children's Literature, 41(1), 32-42.

Kunitz, S. (1951). Junior Book of Authors. New York, NY: H.W. Wilson.

Labastida, A. (1966). Nine days to Christmas. New York, NY: The Viking Press. (Original work published 1959)

Lanes, S. G. (1975). A sign of the times: The Caldecott winner for 1975. School Library Journal, 22(3), 28.

Larrick, N. (1965, Sept. 11). The all-white world of children's books. Saturday Review, 63-65.

Lawson, R. (1966). They were strong and good. New York, NY: The Viking Press. (Original work published 1940).

Lembke, R. C. (1962). We met Aurora Labastida of Mexico. Elementary English, 39(1), 46-47. Retrieved from Retrieved from http://www.jstor.org.libaccess.sjlibrary.org/stable/41387484

Lester, J. (1994). John Henry. (J. Pinkney, Illus.) New York, NY: Dial Books

Levine, E. (2007). Henry's freedom box. (K. Nelson, Illus.) New York, NY: Scholastic Press.

Lipkind, W. \& Mordvinoff, N. (1950). The two reds. New York, NY: Harcourt, Brace \& World. 
Martindale, V. (2004). Honoring Alaska's indigenous literature. Retrieved from http://www.ankn.uaf.edu/iks/hail/RavenTrickster.html

McDermott, G. (1974). Arrow to the sun. New York, NY: The Viking Press.

McDermott, G. (1993). Raven. San Diego, CA: Harcourt Brace Jovanovich.

McKissack, P. C. (1988). Mirandy and brother wind. (J. Pinkney, Illus.) New York, NY: Alfred A. Knopf.

Morales, Y. (2014). Viva Frida! New York, NY: Roaring Brook Press.

Mosel, A. (1972). The funny little woman. (B.Lent, Illus.) New York, NY: E. P. Dutton and Company.

Moss, L. (1995). Zin! Zin! Zin! A violin. (M. Priceman, Illus.) New York, NY: Simon \& Schuster Children's Publishing Division

Musgrove, M. (1976). Ashanti to Zulu: African traditions. (L. \& D. Dillon). New York, NY: The Dial Press.

Myers, W. D. (1997) Harlem. (C. Myers, Illus.) New York, NY: Scholastic Press.

Nahson, C. J. (2011). The snowy day and the art of Ezra Jack Keats. New York, NY: The Jewish Museum and Yale University.

Orton Society. (1973). [Review of the book You can write Chinese] Bulletin of the Orton Society, 23, 198. Retrieved from

http://www.jstor.org.libaccess.sjlibrary.org/stable/23769572

Pang, V. O., Colvin, C., Tran, M., \& Barba, R. H.. (1992). Beyond chopsticks and dragons: Selecting Asian-American literature for children. The Reading Teacher, 46(3), 216-224. Retrieved from http://www.jstor.org.libaccess.sjlibrary.org/stable/20201048

Peabody Bimonthly Booknotes. (1945). Selected professional and cultural books for a teacher's library. Peabody Journal of Education, 23(1), 55-64. Retrieved from http://www.jstor.org.libaccess.sjlibrary.org/stable/1489774

Pescosolido, B. A., Grauerholz, E., \& Milkie, M. A. (1997). Culture and conflict: The portrayal of Blacks in U.S. children's picture books through the mid- and latetwentieth century. American Sociological Review, 62(3), 443-464. Retrieved from http://www.jstor.org.libaccess.sjlibrary.org/stable/2657315 
Petersham M. [Maud] \& Petersham, M [Miska]. (1941). An American ABC. New York, NY: MacMillan Publishers.

Pilkey, D. (1996). The paperboy. New York, NY: Orchard Books.

Pinkney, A. D. (1998). Duke Ellington. (B. Pinkney, Illus.) New York, NY: Hyperion Books for Children.

Pinkney, J. (1999). The ugly duckling. New York, NY: Morrow Junior Books.

Politi, L. (1946). Pedro: the angel of Olvera Street. New York, NY: Charles Scribner's Sons.

Politi, L. (1948). Juanita. New York, NY: Charles Scribner's Sons.

Politi, L. (1974). Song of the swallows. New York, NY: Charles Scribner's Sons. (Original work published 1948)

Quinn, S. M. F. (2006). Examining the culture of fatherhood in American children's literature: Presence, interactions, and nurturing behaviors of fathers in Caldecott Award winning picture books (1938-2002). Fathering: A Journal of Theory, Research, \& Practice about Men as Fathers, 4(1), 71-95.

Rappaport, D. (2001). Martin's big words: The life of Dr. Martin Luther King, Jr. (B. Collier, Illus.) New York, NY: Hyperion Books for Children.

Raschka, C. (1993). Yo! Yes? New York, NY: Orchard Books.

Rathman, P. (1995). Officer Buckle and Gloria. New York, NY: G. P. Putnam's Sons.

Reese, D. (2006). Gerald McDermott's Arrow to the sun. Retrieved from http://americanindiansinchildrensliterature.blogspot.com/2006/10/geraldmcdermotts-arrow-to-sun-gerald.html

Reese, D. (2008). McDermott made up the "Dance of Life" in Arrow To The Sun. Retrieved from http://americanindiansinchildrensliterature.blogspot.com/2008/03/mcdermottmade-up-dance-of-life-in.html

Reese, D. (2011). Robert Lawson's "Indians--tame ones" and slaves in Minnesota. Retrieved from http://americanindiansinchildrensliterature.blogspot.com/2011/02/robert-lawsonsindians-tame-ones-and.html 
Reese, D. (2014a). Retrieved from http://americanindiansinchildrensliterature.blogspot.com/2014/06/paul-goblesgirl-who-loved-wild-horses.html

Reese, D. (2014b). About “diverse" books and inclusivity in Brian Floca's Locomotive. Retrieved from http://americanindiansinchildrensliterature.blogspot.com/search/label/Locomotive

Reese, D. (2016). A comparison: d'Aulaire's Abraham Lincoln 1939 and 2015. Retrieved from http://americanindiansinchildrensliterature.blogspot.com/2016/01/acomparison-daulaires-abraham-lincoln.html

Ringgold, F. (1991). Tar beach. New York, NY: Crown Publishers.

Robinson, L. (2016) What do you think about the Caldecott winners? Blog comments retrieved from http://www.hbook.com/2016/01/blogs/calling-caldecott/tell-uswhat-you-think-of-the-winners/

Rocco, J. (2011) Blackout. New York, NY: Disney.

Rollins, C. (1950). Recognizing ourselves. Bulletin of the National Association for Nursery Education, 5(4), 3-5. Retrieved from http://www.jstor.org.libaccess.sjlibrary.org/stable/42723269

San Souci, R. D. (1989). The talking eggs. (J. Pinkney, Illus.) New York, NY: Dial Books for Young Readers.

San Souci, R. D. (1995). The faithful friend. (B. Pinkney, Illus.) New York, NY: Simon $\&$ Schuster Children' Publishing Division.

Santat, D. (2014). The adventures of Beekle: The unimaginary friend. New York, NY: Little, Brown \& Company.

Sasser, T. M. (2014). The snowy day in the civil rights era: Peter's political innocence and the unpublished letters from Langston Hughes, Ellen Tarry, Grace Nail Johnson, and Charlemae Hill Rollins. Children's Literature Association Quarterly, 39(3), 359-384. DOI: 10.1353/chq.2014.0042

Say, A. (1993). Grandfather's journey. Boston, MA: Houghton Mifflin Company.

Scanlon, L. G. (2009). All the world. New York, NY: Simon \& Schuster Children's Publishing Divisions. 
Seale, D. \& Slapin, B. (2005) A broke flute: The native experience in books for children. Lanham, MD: AltaMira Press \& Berkeley, CA: Oyate.

Sieruta, P. (2009) They were strong and good enough for 1940. Retrieved from http://collectingchildrensbooks.blogspot.com/2009/04/they-were-strong-andgood-enough-for.html

Sills-Briegel, T., \& Camp, D. (2001). Using literature to explore social issues. The Clearing House, 74(5), 280-284. Retrieved from http://search.proquest.com.libaccess.sjlibrary.org/docview/196852766?accountid= 10361

Simont, M. (2001). The stray dog. New York, NY: Harper's Children’s Books.

Sims, R.B. (2001). Choosing books. Horn Book Magazine. http://www.hbook.com/2001/09/choosing-books/horn-book-magazine/letterseditor-septemberoctober-2001/

Sis, P. (1998). Tibet: Through the red box. New York, NY: Farrar, Straus \& Giroux.

Sis, P. (2007). The wall: Growing up behind the iron curtain. New York, NY: Farrar, Straus \& Giroux.

Slapin, B. (2012). Smoky Night by Eve Bunting: Misguided effort to help kids understand Rodney King events. Retrieved from http://www.tfcbooks.org/blog/smoky-night-book-review

Sleator, W. (1970). The angry moon. (B. Lent, Illus.) Boston, MA: Little, Brown and Company.

Smith, V. (2013). The 'Caldecott effect.' Children \& Libraries: The Journal of The Association for Library Service to Children 1I(1), 9-13.

Snyder, D. (1988). The boy of the three-year nap. (A. Say, Illus.) Boston, MA: Houghton Mifflin Company.

Steptoe, J. (1987). Mufaro's beautiful daughters. New York, NY: Lothrop, Lee \& Shepard Books.

Stewart, S. (1997). The gardener. (D. Small, Illus.) New York, NY: Farrar, Straus, \& Giroux.

Swanson, S. M. (2008). The house in the night. (B. Krommes, Illus.) New York, NY: Houghton Mifflin. 
Starling, K.S. (2015). Day 8: Katheryn Russell-Brown. The Brown Bookshelf. Retrieved from http://thebrownbookshelf.com/2015/02/08/day-8-katheryn-russell-brown/

Sutherland, Z. (1997). From A to Zena. American Libraries, 28(3), 37-38. Retrieved from http://www.jstor.org.libaccess.sjlibrary.org/stable/25634359

Tate, D. (2008). Sean Qualls, illustrator. The Brown Bookshelf. Retrieved from http://thebrownbookshelf.com/2008/02/05/sean-qualls-illustrator/

Tate, D. (2009). Zetta Elliott. The Brown Bookshelf. Retrieved from http://thebrownbookshelf.com/2009/02/07/zetta-elliott-2/

Tate, D. (2012). Day 11: Bryan Collier The Brown Bookshelf. Retrieved from http://thebrownbookshelf.com/2012/02/11/day-11-bryan-collier/

Ujiie, J., \& Krashen, S. (2006). Are prize-winning books popular among children? An analysis of public library circulation. Knowledge Quest, 34(3), 33-35.

United States Census Bureau. (2015, March 31). People quickfacts. Retrieved from http://quickfacts.census.gov/qfd/states/00000.html

United States Census Bureau. (2016, March). Retrieved from http://www.census.gov/quickfacts/table/PST045215/00

Updike, J. (1999). A child's calendar. (T. S. Hyman, Illus.) New York, NY: Holiday House.

Van Allsburg, C. (1985). The polar express. Boston, MA: Houghton Mifflin.

Verbeten, S. (2013). Small details, huge impact. Children \& Libraries: The Journal of the Association for Library Service to Children, 11(1), 18-20.

We need diverse books. (n.d.). FAQ. Retrieved from http://weneeddiversebooks.org/faq/

Weatherford, C. B. (2006). Moses: When Harriet Tubman led her people to freedom. (K. Nelson, Illus.) New York, NY: Jump at the Sea.

Weatherford, C.B. (2015). Voice of freedom: Fannie Lou Hamer spirit of the civil rights movement. Somerville, MA: Candlewick Press.

Wheeler, O. (1945). Sing mother goose. (M. Torrey, Illus.) New York, NY: E.P. Dutton \& Company. 
Wheeler, O. (1946). Sing in praise. (M. Torrey, Illus.) New York, NY: E. P. Dutton \& Co.

Wiese, K. (1945). You can write Chinese. New York, NY: The Viking Press.

Wiese, K. (1966). Fish in the air. New York, NY: The Viking Press. (Original work published 1948)

Wiesner, D. (1999). Sector 7. New York, NY: Houghton Mifflin Company.

Wiesner, D. (2006). Flotsam. New York, NY: Clarion Books.

Willems, M. (2004). Knuffle bunny. New York, NY: Hyperion Books for Children.

Willems, M. (2007). Knuffle bunny, too. New York, NY: Hyperion Books for Children.

Williams, J. A., Podeschi, C., Palmer, N., Schwadel, P., \& Meyler, D. (2012). The human-environment dialog in award-winning children's picture books. Sociological Inquiry, 82(1), 145-159.

Williams, S. A. (1992). Working cotton. (C. Byard, Illus.) San Diego, CA: Harcourt, Brace, Jobanovich.

Williams, V. B. (1982). A chair for my Mother. New York, NY: Greenwillow Books.

Williams, V. B. (1990). More more more said the baby. New York, NY: Greenwillow Books.

Williams, V. K., \& Deyoe, N. (2014). Diverse population, diverse collection? Youth collections in the United States. Technical Services Quarterly, 31(2), 97-121.

Woodson, J. (2004). Coming on home soon. (E. B. Lewis, Illus.) New York, NY: G. P. Putnam's Sons.

Woodson, J. (2014). The pain of the watermelon joke. The New York Times. Retrieved from http://www.nytimes.com/2014/11/29/opinion/the-pain-of-the-watermelonjoke.html

Yashima, T. (1955). Crow boy New York, NY: The Viking Press.

Yashima, T. (1967). Seashore story. New York, NY: The Viking Press.

Yashima, T. (1969). Umbrella. New York, NY: The Viking Press. (Original work published 1958) 
Yolen, J. (1998). The emperor and the kite. (E. Young, Illus.) New York, NY: The Putnam \& Grosset Group. (Original work published 1967)

Young, E. (1989). Lon Po Po. New York, NY: Philomel Books.

Zeece, P. D. (1999). And the winner is: Children's literature awards and accolades. Early Childhood Education Journal, 26(4), 233-244. 


\section{Appendix: Caldecott Award Winners}

Aardema, V. (1975). Why mosquitos buzz in people’s ears. (L. \& D. Dillon, Illus.) New York, NY: The Dial Press.

Ackerman, K. (1988). Song and dance man. (S. Gammell, Illus.) New York, NY: Alfred A. Knopf.

Anderson, H.C. (1953). The steadfast tin soldier (M. Brown, Illus.) New York, NY: Charles Scribner's Sons.

Andrews, T. (2015). Trombone Shorty. New York, NY: Abrams Books for Young Readers.

Armer, L. A. (1938). The forest pool. London, England: Longman Publishing Group.

Arthur, M. (1990). Puss in boots. (F. Marcellino, Illus.) New York, NY: Farrar, Straus \& Giroux.

Artzybasheff, B. (1937). Seven Simeons: A Russian tale. New York, NY: The Viking Press.

Baker, O. (1981). Where the buffaloes begin. (S. Gammel, Illus.) New York, NY: Frederick Warne \& Co.

Bang, M. (1980). The grey lady and the strawberry snatcher. New York, NY: Simon \& Schuster Children's Publishing.

Bang, M. (1983). Ten, nine, eight. New York, NY: Greenwillow Books.

Bang, M. (1999). When Sophie gets angry - Really, really angry... New York, NY: The Blue Sky Press.

Barnett, M. (2012). Extra yarn. (J. Klassen, Illus.) New York, NY: Harper Collins Children's Books.

Barnett, M. (2014). Sam \& Dave dig a hole. (J. Klassen, Illus.) Somerville, MA: Candlewick Press.

Bartone, E. (1993). Peppe the lamplighter. (T. Lewin, Illus.) New York, NY: Lothrop, Lee \& Shepard Books.

Baskin, H, Baskin, T, \& Baskin, L. (1972). Hosie's alphabet. (L. Baskin, Illus.) New York, NY: The Viking Press.

Baylor, B. (1972). When clay sings. (T. Bahti, Illus.) New York, NY: Charles Scribner's Sons. 
Baylor, B. (1975). The desert is theirs. (P. Parnall, Illus.) New York, NY: Charles Scribner's Sons.

Baylor, B. (1976). Hawk, I'm your brother. (P. Parnall, Illus.) New York, NY: Charles Scriber's Sons.

Baylor, B. (1978). The way to start a day. (P. Parnall, Illus.) New York, NY: Charles Scriber's Sons.

Becker, A. (2013). Journey. Somerville, MA: Candlewick Press.

Belting, N. M. (1962). The sun is a golden earring. (B. Bryson, Illus.) New York, NY: Holt, Rinehart and Winston.

Bemelmans, L. (1960). Madeline. New York, NY: The Viking Press. (Original work published 1939).

Bemelmans, L. (1970). Madeline's rescue. New York, NY: The Viking Press (Original work published 1953).

Birnbaum, A. (1973). Green eyes. Racine, WI: Western Publishing, Inc. (Original work published 1953).

Brown, M. (1947). Stone soup: An old tale. New York, NY: Charles Scribner's Sons.

Brown, M. (1949). Henry-Fisherman: A story of the Virgin Islands. New York, NY: Charles Scribner's Sons.

Brown, M. (1950). Dick Whittington and his cat. New York, NY: Charlies Scribner's Sons.

Brown, M. (1951). Skipper John's cook. New York, NY: Scribner.

Brown, M. (1952). Puss in boots. New York, NY: Charles Scribner's Sons.

Brown, M. (1954). Cinderella. New York, NY: Charles Scribner’s Sons.

Brown, M. (1961). Once a mouse... New York, NY: Charles Scribner's Sons.

Brown, M. (1982). Shadow. New York, NY: Charles Scribner's Sons.

Brown, M. W. (1954). Wheel on the chimney. (T. Gergely, Illus.) New York, NY: J.B. Lippincott

Brown, M. W. (1992). A child's good night book. (J. Charlot, Illus.) New York, NY: Harper Collins. (Original work published 1943) 
Bryant, J. (2008). A river of words. (M. Sweet, Illus.) Grand Rapids, MI: Eerdmans Books for Young Readers.

Bryant, J. (2014). The right word: Roget and his thesaurus. (M. Sweet, Illus.) Grand Rapids, MI: Eerdmans Books for Young Readers.

Buff, C. \& Buff, M. (1947). Dash \& Dart. New York, NY: The Viking Press. (Original work published 1942)

Bunting, E. (1994). Smoky night. (D. Diaz, Illus.). San Diego, CA: Harcourt, Brace.

Burton, V. L. (1942). The little house. Boston, MA: Houghton Mifflin.

Buzzeo, T. (2012). One cool friend. (D. Small, Illus.). New York, NY: Dial Books for Young Readers.

Carrick, L. C. (2009). Dave the potter. NewYork, NY: Little Brown and Company.

Castillo, L. (2014). Nana in the city. New York, NY: Clarion Books.

Caudill, R. (1964). A pocketful of cricket. (E. Ness, Illus.) New York, NY: Holt, Rinehart and Winston.

Chan, C. (1943). Good-luck horse. (P. Chan, Illus.) New York, NY: McGraw-Hill Book Company

Chodos-Irvine, M. (2003). Ella Sarah gets dressed. San Diego, CA: Harcourt.

Clark, A. N. (1969). In my mother's house. (V. Herrara, Illus.) New York, NY: The Viking Press (Original work published 1941)

Cooney, B. (1958). Chanticleer and the fox. New York, NY: Thomas Y. Crowell.

Crews, D. (1978). Freight train. New York, NY: Greenwillow Books.

Crews, D. (1980). Truck. New York, NY: Greenwillow Books.

Cronin, D. (2000). Click, clack, moo cows that type. (B. Lewin, Illus.) New York, NY: Simon \& Schuster Books for Young Readers.

de Angeli, M. (1944). Yonie wondernose. Garden City, NY: Doubleday.

de Angeli, M. (1954). Book of nursery and mother goose rhymes. Garden City, NY: Doubleday. 
d'Aulaire, I.P. \& d'Aulaire E.P. (1957). Abraham Lincoln. Garden City, NY: Doubleday. (Original work published 1939)

Dagliesh, Alice (1988). The Thanksgiving story. (H. Sewell, Illus.) New York, NY: Charles Scribner's Sons. (Original work published 1954)

Daugherty, J. (1964). Andy and the lion. New York, NY: The Viking Press. (Original work published 1938)

Davis, L. R. (1947). Roger and the fox. (H. Woodward, Illus.) Garden City, NY: Doubleday.

Davis, L. R. (1949). The wild birthday cake. (H. Woodward, Illus.) Garden City, NY: Doubleday.

Dayrell, E. (1968). Why the sun and the moon live in the sky. (B. Lent, Illus.) Boston, MA: Houghton Mifflin.

De Paola, T. (1975). Strega Nona. Englewood Cliffs, N. J.: Prentice-Hall, Inc

De Regniers, B. S. (1964). May I bring a friend? (B. Montresor, Illus.) New York, NY: Atheneum.

de la Peña, M. (2015). Last stop on Market street. New York, NY: G.P. Putnam's Sons.

DiTerlizzi, T. (2002). The spider and the fly. New York, NY: Simon \& Schuster Books for Young Readers.

Domanska, J. (1971). If all the seas were one sea. New York, NY: Aladdin Children's Books.

Dr. Seuss (1949). Bartholomew and the oobleck. New York, NY: Random House.

Dr. Seuss (1975). McElligot's pool. New York, NY: Random House, Inc. (Original work published 1947)

Dr. Seuss. (1950). If I ran the zoo. New York, NY: Random House.

Ehlert, L. (1989). Color zoo. New York, NY: J. B. Lippincott.

Eichenberg, F. (1952). Ape in a cape: An alphabet of odd animals. San Diego, CA: Harcourt Brace Jovanovich.

Elkin, B. (1956). Gillespie and guards. (J. Daugherty, Illus.) New York, NY: The Viking Press 
Emberley, B. (1972). Drummer Hoff. (E. Emberley, Illus.) Englewood Cliffs, N. J.: PrenticeHall. (Original work published in 1967)

Emberley, B. (1992). One wide river to cross. (E. Emberley, Illus.) Boston, MA: Little, Brown and Company. (Original work published 1966)

Ets, M. H. (1951). Mr. T.W. Anthony Woo. New York, NY: The Viking Press.

Ets, M.H. (1955). Play with me. New York, NY: The Viking Press.

Ets. M. H. (1956). Mister Penny's race horse. New York, NY: The Viking Press.

Ets, M. H. (1966). Just me. New York, NY: The Viking Press. (Original work published 1965)

Ets, M. H. (1972). In the forest. New York, NY: The Viking Press. (Original work published 1944).

Falconer, I. (2000). Olivia. New York, NY: Antheneum.

Feelings, M. (1971). Moja Means One: Swahili Counting Book. (T. Feelings, Illus.) New York, NY: The Dial Press.

Feelings, M. (1974). Jambo means hello. (T. Feelings, Illus.) New York, NY: The Dial Press.

Field, R. (1944). Prayer for a child. (E. Orton Jones, Illus.) New York, NY: MacMillan.

Fish, H.D. (1937). Animals of the bible. New York, NY: Fredrick A. Stokes Company.

Fish, H.D. (1937). Four \& twenty birds: Nursery rhymes of yesterday recalled for children of today. (R. Lawson, Illus.) Philadelphia, PA: J.B. Lippincott.

Flack, M. (1991). The boats on the river. (J. H. Barnum, Illus.) New York, NY: The Viking Press. (Original work published 1946)

Fleming, D. (1993). In the small, small pond. New York, NY: Henry Holt and Company.

Floca, B. (2013). Locomotive. New York, NY: Simon \& Schuster Children’s Publishing.

Ford, L. (1939). The ageless story. New York, NY: Dodd, Mead and Company.

Frasconi, A. (1958). The house that Jack built: La maison que Jacques a batie. New York, NY: Harcourt, Brace, and Company

Frazee, M. (2008). A couple of boys have the best week ever. San Diego, CA: Harcourt. 
Freeman, D. (1957). Fly high, fly low. New York, NY: The Viking Press

Gag, W. (1938). Snow White and the seven dwarfs. New York, NY: Coward, McCann \& Geoghegan.

Gag, W. (1941). Nothing at all. New York, NY: Coward - McCann.

Gerstein, M. (2003). The man who walked between the towers. Brookfield, CT: Roaring Brook Press.

Giovanni, N. (2005). Rosa. (B. Collier, Illus.) New York, NY: Henry Holt \& Company.

Goble, P. (1978). The girl who loved wild horses. Scarsdale, NY: Bradbury Press.

Goffstein, M. B. (1976). Fish for supper. New York, NY: The Dial Press.

Goudey, A. E. (1959). Houses from the sea. (A. Adams, Illus.) New York, NY: Charles Scribner's Sons.

Goudey, A. E. (1961). The day we saw the sun come up. (A. Adams, Illus.) New York, NY: Charles Scribner's Sons.

Graham, A. (1965). Timothy turtle. (T. Palazzo, Illus.) New York, NY: The Viking Press. (Original work published 1946)

Grifalconi, A. (1986). The village of round and square houses. Boston, MA: Little, Brown \& Company.

Hader, B. \& Hader, E. (1948). The big snow. New York, NY: MacMillan.

Hader, B. \& Hader, E. (1966). Cock-a-doodle doo: The story of a little red rooster. New York, NY: The MacMillan Company. (Original work published 1939)

Hader, B. \& Hader, E. (1967). The mighty hunter. New York, NY: MacMillan. (Original work published 1943)

Haley, Gail. (1971). A story a story. New York, NY: Atheneum. (Original work published 1970).

Hall, D. (1979). Ox-cart man. (B. Cooney, Illus.) New York, NY: The Viking Press.

Handforth, T. (1990). Mei Li. New York, NY: Bantam Doubleday Dell Publishing Group. (Original work published 1938) 
Henkes, K. (1993). Owen. New York, NY: Greenwillow Books.

Henkes, K. (2004). Kitten's first full moon. New York, NY: Harper Collins Children's Books.

Henkes, K. (2015). Waiting. New York, NY: Harper Collins Children's Books.

Hill, L. C. (2010). Dave the potter. (B. Collier, Illus.) New York, NY: Little, Brown \& Company.

Ho, M. (1996). Hush! A Thai lullaby. (H. Meade, Illus.) New York, NY: Orchard Books.

Hodges, M. (1964). The wave. (B. Lent, Illus.) Boston, MA: Houghton Mifflin.

Hodges, M. (1984). Saint George and the dragon. (T. S. Hyman, Illus.) Boston, MA: Little, Brown \& Company.

Hogrogian, N. (1971). One fine day. New York, NY: Macmillan Publishing Company.

Hogrogian, N. (1976). The contest: An Armenian folktale. New York, NY: Greenwillow Books.

Holbrook, S. (1949). America's Ethan Allen (L. Ward, Illus.) Boston, MA: Houghton Mifflin.

Holling, H. C. (1969). Paddle-to-the-sea. Boston, MA: Houghton Mifflin. (Original work published 1941)

Hyman, T. S. (1983). Little red riding hood. New York, NY: Holiday House.

Idle, M. (2013). Flora and the flamingo. San Francisco, CA: Chronicle Books.

Isaacs, A. (1994). Swamp angel. (P. O. Zelinsky, Illus.) New York, NY: Dutton Children's Books.

Isadora, R. (1979). Ben's trumpet. New York, NY: Greenwillow Books.

Jarrell, R. (1972). Snow-White and the seven dwarfs. (N. E. Burkert, Illus.) New York, NY: Farrar, Straus, and Giroux.

Jeffers, S. (1973). Three jovial huntsmen. New York, NY: Aladdin Children's Books.

Jenkins, S. \& Page, R. (2003). What do you do with a tail like this? New York, NY: Houghton Mifflin.

Johnson, S. T. (1995) Alphabet city. New York, NY: Penguin Books. 
Jones, J. O. (1943). Small rain: Verses from the Bible. (E. Orton Jones, Illus.) New York, NY: The Viking Press.

Joslin, S. (1958). What do you say, dear? (M. Sendak, Illus.) New York, NY: Harper \& Row .

Juster, N. (2005). The hello, goodbye window. (C. Raschka, Illus.) New York, NY: Hyperion Books for Children.

Keats, E. J. (1962). The snowy day. New York, NY: The Viking Press.

Keats, E. J. (1969). Goggles! New York, NY: MacMillan.

Kerley, B. K. (2001). The dinosaurs of Waterhouse Hawkins. (B. Selznick, Illus.) New York, NY: Scholastic Press.

Kepes, J. (1952). Five little monkeys. Cambridge, MA: The Riverside Press.

Kimmel, E. (1989). Hershel and the Hanukkah goblins. (T. S. Hyman, Illus.) New York, NY: Holiday House.

Kingman, L. (1943). Pierre Pidgeon. (A. E. Bare, Illus.) Boston, MA: Houghton Mifflin.

Klassen, J. (2012). This is not my hat. Somerville, MA: Candlewick Press.

Krauss, R. (1989). The happy day (M. Simont, Illus.) New York, NY: Harper \& Row Junior Books. (Original work published 1949)

Krauss, R. (1981). A very special house. (M. Sendak, Illus.) New York, NY: Harper Collins. (Original work published 1953)

Labastida, A. (1966). Nine days to Christmas. New York, NY: The Viking Press. (Original work published 1959)

Langstaff, J. (1955). Frog went a-courtin' (F. Rojankovsky, Illus.) New York, NY: Harcourt, Brace \& World.

Lawson, R. (1966). They were strong and good. New York, NY: The Viking Press. (Original work published 1940)

Leaf, M. (1938). Wee Gillis. (R. Lawson, Illus.) New York, NY: The Viking Press.

Lehman, B. (2004). The red book. Boston, MA: Houghton Mifflin. 
Leodhas, S. N. (1963). All in the morning early. (E. Ness, Illus.) New York, NY: Holt, Rinehart and Winston.

Leodhas, S. N. (1965). Always rooms for one more. (N. Nogrogian, Illus.) New York, NY: Holt, Rinehard and Winston.

Lesser, R. (1984). Hansel and Gretel. (P. O. Zelinsky, Illus.) New York, NY: Dodd, Mead \& Company.

Lester, J. (1994). John Henry. (J. Pinkney, Illus.) New York, NY: Dial Books.

Levine, E. (2007). Henry's freedom box. (K. Nelson, Illus.) New York, NY: Scholastic Press.

Lionni, L. (1960). Inch by inch. Brooklyn, NY: Columbia Lithographic Company.

Lionni, L. (1963). Swimmy. New York, NY: Pantheon Books.

Lionni, L. (1967). Frederick. New York, NY: Pantheon Books.

Lionni, L. (1997). Alexander and the wind-up mouse. New York, NY: Pantheon Books. (Original work published 1969)

Lipkind, W. \& Mordvinoff, N. (1950). The two reds. New York, NY: Harcourt, Brace \& World.

Lipkind, W. \& Mordvinoff, N. (1951). Finders keepers. New York, NY: Harcourt, Brace \& World.

Lobel, A. (1970). Frog and toad are friends. New York, NY: Harper \& Row.

Lobel, A. (1980). Fables. New York, NY: Harper \& Row.

Lobel, A. (1981). On market street. (Arnold Lobel, Illus.) New York, NY: Greenwillow Books.

Logue, M. (2012). Sleep like a tiger. (P. Zaraenski, Illus.) Boston, MA: Houghton Mifflin Books for Children.

Low, J. (1980). Mice twice. New York, NY: Atheneum.

Macaulay, D. (1973). Cathedral: The story of its construction. New York, NY: Houghton Mifflin Harcourt.

Macaulay, D. (1977). Castle. Boston, MA: Houghton Mifflin Company

Macaulay, D. (1990). Black and white. Boston, MA: Houghton Mifflin. 
MacDonald, G. (1945). Little lost lamb. (L. Weisgard, Illus.) Garden City, NY: Doubleday \& Company.

MacDonald, G. (1946). The little island. Garden City, NY: Doubleday \& Company.

MacDonald, S. (1986). Alphabatics. New York, NY: Bradbury Press.

Malcolmson, A. \& Castagnetta, G. (1947). Song of Robin Hood (V. L. Hurton, Illus.) Boston, MA: Houghton Mifflin.

Marshall, J. (1988). Goldilocks and the three bears. New York, NY: Dial Books for Young Readers.

Martin, J. B. (1998). Snowflake Bentley. (M. Azarian, Illus.) New York, NY: Houghton Mifflin.

Mattick, L. (2015). Finding Winnie: The true story of the world's most famous bear. New York, NY: Little Brown and Company

McCarty, P. (2002). Hondo \& Fabian. New York, NY: Henry Holt and Company.

McCloskey, R. (1969). Make way for ducklings. New York, NY: The Viking Press. (Original work published 1941)

McCloskey, R. (1976). Blueberries for Sal. New York, NY: The Viking Press. (Original work published 1948)

McCloskey, R. (1980). One morning in Maine. New York, NY: The Viking Press. (Originally work published 1952)

McCloskey, R. (1985). Time of wonder. New York, NY: The Viking Press. (Original work published 1957)

McCully, E. A. (1992). Mirette on the high wire. New York, NY: G. P. Putnam's Sons.

McDermott, B. B. (1976). The golem: A Jewish legend. Philadelphia, PA: J. B. Lippincott Company.

McDermott, G. (1972). Anansi the spider. New York, NY: Holt, Reinhart and Winston.

McDermott, G. (1974). Arrow to the sun. New York, NY: The Viking Press.

McDermott, G. (1993). Raven: A trickster tale from the Pacific northwest. San Diego, CA: Harcourt Brace Jovanovich. 
McDonnell, P. (2011). Me ... Jane. New York, NY: Little, Brown \& Company.

McGinley, P. (1948). All around town. (H. Stone, Illus.) Philadelphia, PA: J. B. Lippincott Company.

McGinley, P. (1990). The most wonderful doll in the world. New York, NY: Scholastic. (Original work published 1950)

McKissack, P. C. (1988). Mirandy and brother wind. (J. Pinkney, Illus.) New York, NY: Alfred A. Knopf.

McLimans, D. (2006). Gone wild: An endangered animal alphabet. New York, NY: Walker Publishing Company.

Milhous, K. (1950). The egg tree. New York, NY: Charles Scribner’s Sons.

Minarik, E. H. (1961). Little bear's visit. (M. Sendak, Illus.) New York, NY: Harper \& Row.

Morales, Y. (2014). Viva Frida! New York, NY: Roaring Brook Press.

Mosel, A. (1972). The funny little woman. (B.Lent, Illus.) New York, NY: E. P. Dutton and Company.

Moss, L. (1995). Zin! Zin! Zin! A violin. (M. Priceman, Illus.) New York, NY: Simon \& Schuster Children's Publishing Division

Musgrove, M. (1976). Ashanti to Zulu: African traditions. (L. \& D. Dillon). New York, NY: The Dial Press.

Muth, J. J. (2005). Zen shorts. New York, NY: Scholastic Press.

Myers, W. D. (1997) Harlem. (C. Myers, Illus.) New York, NY: Scholastic Press.

Ness, E. (1965). Tom Tit Tot. New York, NY: Charles Scribner's Sons.

Ness, E. (1966). Sam, Bangs \& Moonshine. New York, NY: Holt, Rinehart and Winston.

Newberry, C. T. (1938). Barkis. New York, NY: Harper \& Brothers.

Newberry, C.T. (1940). April's kittens. Eau Claire, WI: E. M. Hale and Company.

Newberry, C. T. (1950). T-bone: The babysitter. New York, NY: Harper \& Brothers. 
Newberry, C. T. (1990). Marshmallow. New York, NY: Harper \& Row. (Original work published 1942)

Olds, E. (1951). Feather Mountain. Boston, MA: Houghton Mifflin Company.

Peet, B. (1989). Bill Peet: An autobiography. Boston, MA: Houghton Mifflin.

Pelletier, D. (1996). The graphic alphabet. New York, NY: Orchard Books.

Pene du Bois, W. (1951). Bear party. New York, NY: The Viking Press.

Pene du Bois, W. (1956). Lion. New York, NY: The Viking Press.

Petersham M. \& Petersham, M. (1941). An American ABC. New York, NY: The MacMillan Company.

Petersham, M. \& Petersham, M. (1945). The rooster crows. New York, NY: Macmillan Publishing Co..

Pilkey, D. (1996). The paperboy. New York, NY: Orchard Books.

Pinkney, A. D. (1998). Duke Ellington. (B. Pinkney, Illus.) New York, NY: Hyperion Books for Children.

Pinkney, J. (1999). The ugly duckling. New York, NY: Morrow Junior Books.

Pinkney, J. (2002). Noah's Ark. New York, NY: SeaStar Books.

Pinkney, J. (2009). The lion and the mouse. New York, NY: Little Brown Books for Young Readers.

Plume, I. (1980). The Bremen-town musicians. New York, NY: Harper Trophy

Politi, L. (1946). Pedro: the angel of Olvera Street. New York, NY: Charles Scribner's Sons.

Politi, L. (1948). Juanita. New York, NY: Charles Scribner's Sons.

Politi, L. (1974). Song of the swallows. New York, NY: Charles Scribner's Sons. (Original work published 1948)

Preston, E. M. (1969). Pop corn \& ma Goodness. (R. A. Parker, Illus.) New York, NY: The Viking Press. 
Priceman, M. (2005). Hot air: The (mostly) true story of the first hot-air balloon ride. New York, NY: Atheneum Books for Young Readers.

Provensen, A., \& Provensen, M. (1983). The glorious flight. New York, NY: The Viking Press.

Ransome, A. (1968). The fool of the world and the flying ship. (U. Shulevitz, Illus.) New York, NY: Farrar, Straus and Giroux.

Rappaport, D. (2001). Martin's big words: The life of Dr. Martin Luther King, Jr. (B. Collier, Illus.) New York, NY: Hyperion Books for Children.

Raschka, C. (1993). Yo! Yes? New York, NY: Orchard Books.

Raschka, C. (2011). A ball for Daisy. New York, NY: Schwartz \& Wade Books.

Rathman, P. (1995). Officer Buckle and Gloria. New York, NY: G. P. Putnam’s Sons.

Reed, P. (1963). Mother Goose and nursery rhymes. New York, NY: Athenuem.

Reyher, B. (1965). My mother is the most beautiful woman in the world. (R. Gannett, Illus.) Boston, MA: Lothrop, Lee \& Shepard Co., Inc. (Original work published 1945)

Reynolds, A. (2012). Creepy carrots! (P. Brown, Illus.) New York, NY: Simon \& Schuster Children's Publishing.

Ringgold, F. (1991). Tar beach. New York, NY: Crown Publishers.

Robbins, R. (1960). Baboushka and the three kings (N. Sidjakov, Illus.) Berkeley, CA: Parnassus Press.

Rocco, J. (2011) Blackout. New York, NY: Disney.

Rohmann, E. (1994). Time flies. New York, NY: Crown Publishers.

Rohmann, E. (2002). My friend rabbit. Brookfield, CT: Roaring Book Press.

Rosenstock, B. (2014). The noisy paint box. (M. Grandpre, Illus.) New York, NY: Alfred A. Knopf.

Ryan, C. D. (1971). Hildilid's night. (A. Lobel, Illus.) New York, NY: Macmillan Publishing Company.

Rylant, C. (1982). When I was young in the mountains. (D. Goode, Illus.) New York, NY: Dutton Children's Books. 
Rylant, C. (1985). The relatives came. (S. Gammell, Illus.) New York, NY: Bradbury Press.

San Souci, R. D. (1989). The talking eggs. (J. Pinkney, Illus.) New York, NY: Dial Books for Young Readers.

San Souci, R. D. (1995). The faithful friend. (B. Pinkney, Illus.) New York, NY: Simon \& Schuster Children' Publishing Division.

Santat, D. (2014). The adventures of Beekle: The unimaginary friend. New York, NY: Little, Brown \& Company.

Sawyer, R. (1944). The Christmas Anna angel. (K. Seredy, Illus.) New York, NY: The Viking Press.

Sawyer, R. (1953). Journey cake, ho! (R. McCluskey, Illus.) New York, NY: The Viking Press.

Say, A. (1993). Grandfather's journey. Boston, MA: Houghton Mifflin Company.

Scanlon, L. G. (2009). All the world. New York, NY: Simon \& Schuster Children's Publishing Divisions.

Scheer, J. (1964). Rain makes applesauce. (M. Bileck, Illus.) New York, NY: Holiday House.

Schlein, M. (1954). When will the world be mine? New York, NY: William R. Scott.

Schreiber, G. (1947). Bambino the clown. New York, NY: The Viking Press.

Scieszka, J. \& Smith, L. (1992). The stinky cheese man and other fairly stupid tales. New York, NY: Penguin Books.

Seeger, L. V. (2007). First the egg. New Milford, CT: Roaring Brook Press.

Seeger, L. V. (2012). Green. New York, NY: Roaring Brook Press.

Selznick, B. (2007). The invention of Hugo Cabaret. New York, NY: Scholastic Press.

Sendak, M. (1963). Where the wild things are. New York, NY: Harper \& Row.

Sendak, M. (1970). In the night kitchen. New York, NY: Harper \& Row.

Sendak, M. (1981). Outside over there. New York, NY: Harper \& Row.

Shannon, D. (1998). No, David! New York, NY: The Blue Sky Press. 
Shulevitz, U. (1980). The treasure. New York, NY: Farrar, Straus, \& Giroux. (Original work published 1978).

Shulevitz, U. (1998). Snow. New York, NY: Farrar, Straus, \& Giroux.

Shulevitz, U. (2008). How I learned geography. New York, NY: Farrar, Straus, \& Giroux.

Sidman, J. (2005) Song of the water boatman \& other pond poems. (B. Prange, Illus.) Boston, MA: Houghton Mifflin Company.

Sidman, J. (2009). Red sings from treetops. (P. Zagarenski, Illus.) New York, NY: Houghton Mifflin Books for Children.

Simont, M. (2001). The stray dog. New York, NY: Harper's Children’s Books.

Sis, P. (1996). Starry messenger. New York, NY: Farrar, Straus, \& Giroux.

Sis, P. (1998). Tibet: Through the red box. New York, NY: Farrar, Straus \& Giroux.

Sis, P. (2007). The wall: Growing up behind the iron curtain. New York, NY: Farrar, Straus \& Giroux.

Sleator W. (1970). The angry moon. (B. Lent, Illus.) Boston, MA: Little, Brown and Company.

Smith, L. (2011). Grandpa Green. New York, NY: Roaring Brook Press.

Snyder, D. (1988). The boy of the three-year nap. (A. Say, Illus.) Boston, MA: Houghton Mifflin Company.

Spier, P. (1961). The fox went out on a chilly night. Garden City, NY: Doubleday \& Company.

Spier, P. (1977). Noah's Ark. Garden City, NY: Doubleday \& Company.

St. George, J. (2000). So you want to be president? (D. Small, Illus.) New York, NY: Philomel Books.

Stead, P. C. (2010). A sick day for Amos McGee. (E. E. Stead, Illus.) New York, NY: Roaring Brook Press.

Steig, W. (1969) Sylvester and the magic pebble. New York, NY: Windmill Books, Simon and Schuster. 
Steig, W. (1977). The amazing bone. New York, NY: Farrar, Straus, \& Giroux. (Original work published 1976).

Stein, D. E. (2010). Interrupting chicken. Somerville, MA: Candlewick Press.

Steptoe, J. (1984). The story of jumping mouse. New York, NY: Lothrop, Lee \& Shepard Books.

Steptoe, J. (1987). Mufaro's beautiful daughters. New York, NY: Lothrop, Lee \& Shepard Books.

Stevens, J. (1995). Tops \& bottoms. (J. Stevens, Illus.) San Diego, CA: Harcourt, Brace \& Company.

Stewart, S. (1997). The gardener. (D. Small, Illus.) New York, NY: Farrar, Straus, \& Giroux.

Swanson, S. M. (2008). The house in the night. (B. Krommes, Illus.) New York, NY: Houghton Mifflin.

Taback, S. (1997). There was an old lady who swallowed a fly. New York, NY: Viking Press.

Taback, S. (1999). Joseph had a little overcoat. New York, NY: Viking Press.

Tafuri, N. (1984). Have you seen my duckling? New York, NY: Greenwillow Books.

Tamaki, M. (2014). This one summer. (J. Tamaki, Illus.) New York, NY: First Second.

Thayer, E. L. (2000). Casey at the bat. (C. Bing, Illus.) San Francisco, CA: Chronicle Books.

Thurber, J. (1971). Many moons. (L. Slobodkin, Illus.) New York, NY: Harcourt, Brace \& World. (Original work published 1943)

Titus, E. (1956). Anatole. (P. Galdone, Illus.) New York, NY: McGraw-Hill Book Company.

Titus, E. (1957). Anatole and the cat. (P. Galdone, Illus.) New York, NY: McGraw-Hill Book Company.

Tresselt, A. (1946). Rain drop splash. New York, NY: Lothrop, Lee \& Shepard.

Tresselt, A. (1962). White snow, bright snow. (R. Duvoisin, Illus.) New York, NY: Lothrop, Lee $\&$ Shepard. (Original work published 1947)

Tresselt, A. (1965). Hide and seek fog. (R. Duvoisin, Illus.) New York, NY: Lothrop, Lee \& Shephard. 
Tudor, T. (1944). Mother Goose. New York, NY: Oxford University Press.

Tudor, T. (1956). 1 is one. New York, NY: MacMillian Publishing Company.

Turkle, B. (1969). Thy friend, Obadiah. New York, NY: The Viking Press.

Udry, J. (1956). A tree is nice. (M. Simont, Illus.) New York, NY: Harper \& Row.

Udry, J. M. (1959). The moon jumpers (M. Sendak, Illus.) New York, NY: Harper \& Row.

Updike, J. (1999). A child's calendar. (T. S. Hyman, Illus.) New York, NY: Holiday House.

Van Allsburg, C. (1979). The garden of Abdul Gasazi. Boston, MA: Houghton Mifflin.

Van Allsburg, C. (1981). Jumanji. Boston, MA: Houghton Mifflin.

Van Allsburg, C. (1985). The polar express. Boston, MA: Houghton Mifflin.

Ward, L. (1952). The biggest bear. Cambridge, MA: The Riverside Press.

Weatherford, C. B. (2006). Moses: When Harriet Tubman led her people to freedom. (K. Nelson, Illus.) New York, NY: Jump at the Sea.

Weatherford, C.B. (2015). Voice of freedom: Fannie Lou Hamer spirit of the civil rights movement. Somerville, MA: Candlewick Press.

Wheeler, O. (1945). Sing mother goose. (M. Torrey, Illus.) New York, NY: E.P. Dutton \& Company.

Wheeler, O. (1946). Sing in praise. (M. Torrey, Illus.) New York, NY: E. P. Dutton \& Co.

Wiese, K. (1945). You can write Chinese. New York, NY: The Viking Press.

Wiese, K. (1966). Fish in the air. New York, NY: The Viking Press. (Original work published 1948)

Wiesner, D. (1988). Free fall. New York, NY: Lothrop, Lee \& Shepard Books.

Wiesner, D. (1991). Tuesday. New York, NY: Clarion Books.

Wiesner, D. (1999). 7 sector 7. New York, NY: Houghton Mifflin Company.

Wiesner, D. (2001). The three pigs. New York, NY: Clarion Books. 
Wiesner, D. (2006). Flotsam. New York, NY: Clarion Books.

Wiesner, D. (2013). Mr. Wuffles! New York, NY: Clarion Books.

Willard, N. (1981). A visit to William Blake's inn: Poems for innocent and experienced travelers. (A. \& M. Provensen, Illus.) San Diego, CA: Harcourt, Brace \& Company.

Willems, M. (2003). Don't let the pigeon drive the bus! New York, NY: Hyperion Books for Children.

Willems, M. (2004). Knuffle bunny. New York, NY: Hyperion Books for Children.

Willems, M. (2007). Knuffle bunny too. New York, NY: Hyperion Books for Children.

Williams, S. A. (1992). Working cotton. (C. Byard, Illus.) San Diego, CA: Harcourt, Brace, Jobanovich.

Williams, V. B. (1982). A chair for my Mother. New York, NY: Greenwillow Books.

Williams, V. B. (1990). More more more said the baby. New York, NY: Greenwillow Books.

Wisniewski, D. (1996). Golem. New York, NY: Houghton Mifflin Company.

Wood, A. (1985). King Bidgood's in the bathtub. (D. Wood, Illus.) San Diego, CA: Harcourt, Brace, Jovanovich.

Woodson, J. (2004). Coming on home soon. (E. B. Lewis, Illus.) New York, NY: G. P. Putnam's Sons.

Yashima,T. (1955). Crow boy New York, NY: The Viking Press.

Yashima, T. (1967). Seashore story. New York, NY: The Viking Press.

Yashima, T. (1969). Umbrella. New York, NY: The Viking Press. (Original work published 1958)

Yolen, J. (1998). The emperor and the kite. (E. Young, Illus.) New York, NY: The Putnam \& Grosset Group. (Original work published 1967)

Yolen, J. (1987). Owl moon. (J. Schoenherr, Illus.) New York, NY: Philomel Books.

Yorinks, A. (1986). Hey, Al. (R. Egielski, Illus.) New York, NY: Farrar, Straus \& Giroux.

Young, E. (1989). Lon Po Po. New York, NY: Philomel Books. 
Young, E. (1992). Seven blind mice. New York, NY: Philomel Books.

Zelinsky, P. (1986). Rumpelstiltskin. New York, NY: E. P. Dutton.

Zelinsky, P. (1997). Rapunzel. New York, NY: Dutton Children's Books.

Zemach, H. (1969). The judge. (M. Zemach, Illus.) New York, NY: Farrar, Straus \& Giroux.

Zemach, H. (1973). Duffy and the devil. (M. Zemach, Illus.) New York, NY: Farrar, Straus and Giroux.

Zemach, M. (1978). It could always be worse. New York, NY: Farrar, Straus, \& Giroux. (Original work published 1976).

Zion, G. (1951). All falling down. (M. B. Graham, Illus.) New York, NY: Harper \& Row, Publisher.

Zolotow, C. (1962). Mr. Rabbit and the lovely present. (M. Sendak, Illus.) New York, NY: Harper \& Row.

Zolotow, C. (1989). The storm book. (M.B. Graham, Illus.) New York, NY: Harper Collins. (Original work published 1952). 